\title{
Review \\ Cell Therapy for Anal Sphincter Incontinence: Where Do We Stand?
}

\author{
Alexandre Balaphas ${ }^{1,2}, *$, Jeremy Meyer ${ }^{1}$, Raphael P. H. Meier ${ }^{3}$, Emilie Liot ${ }^{1}$, Nicolas C. Buchs ${ }^{1}$, Bruno Roche ${ }^{1}(\mathbb{D}$, \\ Christian Toso ${ }^{1}$, Leo H. Bühler ${ }^{4}$, Carmen Gonelle-Gispert ${ }^{4}$ (I) and Frédéric Ris ${ }^{1}$ (I)
}

1 Division of Digestive Surgery, University Hospitals of Geneva, 1205 Geneva, Switzerland; jeremy.meyer@hcuge.ch (J.M.); emilie.liot@hcuge.ch (E.L.); nicolas.c.buchs@hcuge.ch (N.C.B.); bruno.roche@grangettes.ch (B.R.); christian.toso@hcuge.ch (C.T.); frederic.ris@hcuge.ch (F.R.)

2 Department of Surgery, Geneva Medical School, University of Geneva, 1205 Geneva, Switzerland

3 Department of Surgery, University of Maryland School of Medicine, Baltimore, MD 21201, USA; RMeier@som.umaryland.edu

4 Faculty of Science and Medicine, University of Fribourg, 1700 Fribourg, Switzerland; leo.buhler@unifr.ch (L.H.B.); carmen.gonelle@unifr.ch (C.G.-G.)

* Correspondence: alexandre.balaphas@hcuge.ch

Citation: Balaphas, A.; Meyer, J.; Meier, R.P.H.; Liot, E.; Buchs, N.C.; Roche, B.; Toso, C.; Bühler, L.H.; Gonelle-Gispert, C.; Ris, F. Cell Therapy for Anal Sphincter Incontinence: Where Do We Stand? Cells 2021, 10, 2086. https:/ / doi.org/10.3390/cells10082086

Academic Editor: Mehdi Najar

Received: 30 June 2021

Accepted: 6 August 2021

Published: 13 August 2021

Publisher's Note: MDPI stays neutral with regard to jurisdictional claims in published maps and institutional affiliations.

Copyright: (c) 2021 by the authors. Licensee MDPI, Basel, Switzerland. This article is an open access article distributed under the terms and conditions of the Creative Commons Attribution (CC BY) license (https:// creativecommons.org/licenses/by/ $4.0 /)$.

\begin{abstract}
Anal sphincter incontinence is a chronic disease, which dramatically impairs quality of life and induces high costs for the society. Surgery, considered as the best curative option, shows a disappointing success rate. Stem/progenitor cell therapy is pledging, for anal sphincter incontinence, a substitute to surgery with higher efficacy. However, the published literature is disparate. Our aim was to perform a review on the development of cell therapy for anal sphincter incontinence with critical analyses of its pitfalls. Animal models for anal sphincter incontinence were varied and tried to reproduce distinct clinical situations (acute injury or healed injury with or without surgical reconstruction) but were limited by anatomical considerations. Cell preparations used for treatment, originated, in order of frequency, from skeletal muscle, bone marrow or fat tissue. The characterization of these preparations was often incomplete and stemness not always addressed. Despite a lack of understanding of sphincter healing processes and the exact mechanism of action of cell preparations, this treatment was evaluated in 83 incontinent patients, reporting encouraging results. However, further development is necessary to establish the correct indications, to determine the most-suited cell type, to standardize the cell preparation method and to validate the route and number of cell delivery.
\end{abstract}

Keywords: anal incontinence; fecal incontinence; stem cell; progenitor cell; mulitipotent cell; myoblast; satellite cell; mesenchymal stem cell; mesenchymal stromal cell

\section{Introduction}

Anal sphincter incontinence (ASI) is defined by an involuntary loss of gases, solids and/or liquid materials. The prevalence of ASI is widely underestimated and ranges from 0.4 to $24 \%$ [1]. ASI is an underrated pathology in regards to its morbidity and its impact on the society and is associated with impaired quality of life and psychopathologies such as depression, anxiety disorder and impaired sexual function [2]. In the USA, ASI's global cost has been estimated to be around 11 billion dollars per year [2].

The physiopathology of ASI is not completely understood but results from a functional impairment of one or more of the four anatomic components that allow a normal continence: The internal anal sphincter (IAS), the external anal sphincter (EAS), the pelvic floor muscles and the sensory-motor apparatus [3]. ASI is primarily managed conservatively but sphincter repair surgery is proposed for large defects of either EAS, IAS or both with conservative treatment failure [4,5]. However, long-term results of anal sphincter repair are unsatisfactory, notably regarding IAS repair [6-9]. Several strategies have been developed 
to improve sphincter repair surgery or to replace it without outstanding successes [10-12]. Since more than a decade, the transplantation of stem cells (multipotent cells with limited proliferation ability) or progenitor cells (multipotent cells with limited proliferation ability) has been proposed as an adjunct or direct therapy for ASI following the hypothesis that transplanted cells will either commit differentiation into EAS or IAS muscle or produce growth factors that will favor sphincter healing (Table S1). A consensus among researchers was never reached, and various source cells and protocols have been proposed and investigated with preclinical and clinical studies. We present herein a critical analysis of cell therapy for ASI. Of note, as transplanted cells were heterogenous regarding their origin and phenotype, the generic term "multipotent cell" will be used to describe the transplanted cells.

\section{Physiopathology of Anal Sphincter Injuries, Models and Cell Therapy-Based Strategies}

\subsection{Mechanisms of Sphincter Injuries}

In patients with ASI, there are at least two mechanisms leading to a modification in the pelvic floor structure or function. First, sphincters can be injured by perineal tearing, stretching and/or ischemia; obstetric trauma being the most common cause [13]. The episiotomy procedure is also associated with anal incontinence [14]. A second mechanism involves the degeneration of pelvic floor muscles, which appears with ageing, but rapidly after menopause as pelvic floor structures are hormone responsive [13]. Proposed animal models of anal incontinence tried to simulate distinct clinical situations where continence is impaired by an acute or chronic mechanism. In these models, various methods were used to harm these structures, including muscle section or excision, thermal injury and even nerve crushing [15] (Table 1). However, these experimental models of ASI do not consider the stretching effect of pelvic floor that can occur during childbirth. Thus, some authors have proposed a more realistic rodent model of childbirth injury by means of a balloon inflated in the vagina for a prolonged time [16,17]. This model was, however, never used to assess the potential of cell therapy to cure ASI.

\subsection{Acute Anal Sphincter Injury and Healing}

The classical clinical situation of acute anal sphincter injury is well illustrated by childbirth trauma, which still occurs in $11 \%$ of vaginal deliveries and can extend up to the IAS and sometimes the rectum (starting from posterior wall of vagina) [18] (Figure 1). In the case of extending traumatism to the level of rectal wall, dedicated stem cells of the anal canal transition zone, positive for cytokeratin 17, participate in the healing process of the mucosa of the rectum and the anal canal [19]. On the other hand, the healing process of anal sphincters has not been thoroughly studied and it is supposed to be very similar to other muscle-healing processes [20]. Under optimal conditions, healing ultimately leads to the generation of new myofibers/smooth muscle cells from muscle satellite cells/progenitor smooth muscle cells or the reparation of damaged myofibers after fusion with muscle satellite cells $[21,22]$. After anal sphincter injury, it is thought that inflammatory cells ${ }^{\prime}$ cross-talk produces cytokines and growth factors that will recruit stem cells and progenitor cells $[20,22]$. These cells could be mobilized from bone marrow or the surrounding tissues and might favor healing, be incorporated into the wound or further recruit stem cells and progenitor cells $[20,22,23]$. Especially, skeletal muscle satellite cells, which are localized in periphery of myofibers, near vascular or nerve structures, are a source of myoblasts and, further, new myocytes after their activation [24,25]. However, Lorenzi et al., reported in rats, after direct anal sphincter injury and repair, the persistence of fibrous tissue with dilated blood vessels and muscle cell degeneration patterns [26]. 
Table 1. Models for anal sphincter incontinence. NHP: Non-human primate.

\begin{tabular}{|c|c|c|c|c|c|c|}
\hline & Designation of Model & $\begin{array}{l}\text { Time Lapse between } \\
\text { Injury and Intervention }\end{array}$ & Publication Reporting the Model & Species & Procedure & Sphincter \\
\hline \multirow{14}{*}{$\begin{array}{c}\text { Acute Anal } \\
\text { Sphincter Injury }\end{array}$} & Sphincterotomy and repair & 0 & $\begin{array}{l}\text { Mazzanti et al., } 2016 \text { [27], Lorenzi et al., } \\
2008 \text { [26] }\end{array}$ & Rat & $\begin{array}{l}\text { Sphincterotomy and primary } \\
\text { repair of sphincters }\end{array}$ & $\begin{array}{l}\text { IAS and } \\
\text { EAS }\end{array}$ \\
\hline & Repaired sphincterotomy & 0 & $\begin{array}{l}\text { Fitzwater et al., } 2015 \text { [28], White et al } 2010 \\
\text { [29], Pathi et al., } 2012 \text { [30] }\end{array}$ & Rat & $\begin{array}{l}\text { Full thickness } 7 \mathrm{~mm} \text { incision of } \\
\text { sphincters followed by repair }\end{array}$ & $\begin{array}{l}\text { IAS and } \\
\text { EAS }\end{array}$ \\
\hline & Anal sphincter injury & 0 & Kuismanen et al., 2018 [31] & Rat & $\begin{array}{l}\text { Incision of full thickness } \\
\text { sphincter with mucosa followed } \\
\text { by mucosa and IAS repair }\end{array}$ & $\begin{array}{l}\text { IAS and } \\
\text { EAS }\end{array}$ \\
\hline & Proctoepisiotomy & 0 & $\begin{array}{c}\text { Lane et al., } 2013 \text { [32], Jacobs et al., } 2013 \\
\text { [33] }\end{array}$ & Rat & Proctoepisiotomy with repair & EAS \\
\hline & Sphincterotomy & 0 & Inoue et al., 2018 [34] & Rat & $\begin{array}{l}\text { Removal of a left semicircle of } \\
\text { sphincter }\end{array}$ & $\begin{array}{l}\text { IAS and } \\
\text { EAS }\end{array}$ \\
\hline & Extra-mucosal myotomy & 0 & Trébol et al., 2018 [35] & Rat & $\begin{array}{l}1 \mathrm{~cm} \text { long incision preserving } \\
\text { the mucosa }\end{array}$ & $\begin{array}{l}\text { IAS and } \\
\text { EAS }\end{array}$ \\
\hline & Anal sphincter cryoinjury & 0 & Bisson et al., 2013 [36] & Rat & $\begin{array}{l}\text { Two cryoinjuries of sphincters at } \\
24 \mathrm{~h} \text { interval with liquid } \\
\text { nitrogen on a } 90^{\circ} \text { sector }\end{array}$ & $\begin{array}{l}\text { IAS and } \\
\text { EAS }\end{array}$ \\
\hline & Anal sphincter cryoinjury & 0 & Kang et al., 2008 [37] & Rat & $\begin{array}{l}\text { Cryoinjury of right } \\
\text { hemi-sphincters }\end{array}$ & $\begin{array}{l}\text { IAS and } \\
\text { EAS }\end{array}$ \\
\hline & Sphincterotomy & 0 & Sarveazad et al., 2019 [38] & Rabbit & Left lateral sphincterotomy & $\begin{array}{l}\text { IAS and } \\
\text { EAS }\end{array}$ \\
\hline & Sphincterotomy & $24 \mathrm{~h}$ & Salcedo et al., 2013 [15] & Rat & $\begin{array}{l}\text { 2-3-mm thick transection of } \\
\text { sphincters }\end{array}$ & $\begin{array}{l}\text { IAS and } \\
\text { EAS }\end{array}$ \\
\hline & Pudendal nerve crush & $24 \mathrm{~h}$ & Salcedo et al., 2013 [15] & Rat & $\begin{array}{c}\text { Posterior incision of } \\
\text { sacro-coccygeal area and } 30 \mathrm{~s} \\
\text { crushing of the nerves on both } \\
\text { sides }\end{array}$ & na \\
\hline & Partial anal sphincter excision & $24 \mathrm{~h}$ and 3 weeks & Salcedo et al., 2014 [39], Li et al., 2020 [40] & Rat & $\begin{array}{c}\text { Excision of } 1 / 3 \text { of ventral anal } \\
\text { sphincters }\end{array}$ & $\begin{array}{l}\text { IAS and } \\
\text { EAS }\end{array}$ \\
\hline & Anal sphincter injury & 2 weeks & Ding et al., 2016 [41] & Rat & $0.2 \mathrm{~cm}$ long sphincters incision & $\begin{array}{l}\text { IAS and } \\
\text { EAS }\end{array}$ \\
\hline & Unrepaired sphincterotomy & 2 weeks & Montoya et al., 2015 [42] & Rat & $\begin{array}{c}\text { Full thickness } 7 \mathrm{~mm} \text { incision of } \\
\text { sphincters }\end{array}$ & $\begin{array}{l}\text { IAS and } \\
\text { EAS }\end{array}$ \\
\hline
\end{tabular}


Table 1. Cont.

\begin{tabular}{|c|c|c|c|c|c|c|}
\hline & Designation of Model & $\begin{array}{c}\text { Time Lapse between } \\
\text { Injury and Intervention }\end{array}$ & Publication Reporting the Model & Species & Procedure & Sphincter \\
\hline \multirow{7}{*}{$\begin{array}{l}\text { Unrepaired Anal } \\
\text { Sphincter Injury }\end{array}$} & $\begin{array}{c}\text { Chronic large anal sphincter } \\
\text { defect }\end{array}$ & 3 weeks & $\begin{array}{l}\text { Sun et al., } 2017 \text { [43], Sun et al., } 2017 \text { [44], } \\
\text { Sun et al., } 2016 \text { [45] }\end{array}$ & Rat & $\begin{array}{l}50 \% \text { excision of ventral portion } \\
\text { of anal sphincters }\end{array}$ & $\begin{array}{l}\text { IAS and } \\
\text { EAS }\end{array}$ \\
\hline & Anal sphincter damage & nd & Li et al., 2018 [46] & Rat & $\begin{array}{l}3 \mathrm{~mm} \text { long incision in the right } \\
\text { posterolateral sphincter }\end{array}$ & $\begin{array}{l}\text { IAS and } \\
\text { EAS }\end{array}$ \\
\hline & $\begin{array}{l}\text { Intersphincteric resection } \\
\text { model }\end{array}$ & na & Yamaguchi et al., 2013 [47] & Rat & $\begin{array}{l}50 \% \text { excision of IAS and a part } \\
\text { of EAS }\end{array}$ & $\begin{array}{l}\text { IAS and } \\
\text { EAS }\end{array}$ \\
\hline & Sphincterotomy & 2 weeks & Aghaee-Afshar et al., 2009 [48] & Rabbit & Right lateral sphincterotomy & EAS \\
\hline & $\begin{array}{l}\text { Excision of external anal } \\
\text { sphincter }\end{array}$ & 3 to 24 weeks & $\begin{array}{l}\text { Kajbafzadeh et al., } 2016 \text { [49], Elmi et al., } \\
2014 \text { [50], Kajbafzadeh et al., } 2010 \text { [51] }\end{array}$ & Rabbit & $\begin{array}{l}\text { Subtotal to total excision of } \\
\text { posterior sphincter }\end{array}$ & EAS \\
\hline & Sphincter injury & 4 weeks & $\begin{array}{l}\text { Oh et al., } 2015 \text { [52], Oh et al., } 2015 \text { [53], } \\
\text { Kang et al., } 2013 \text { [54] }\end{array}$ & Dog & $\begin{array}{l}\text { Resection of } 25 \% \text { of posterior } \\
\text { anal sphincters }\end{array}$ & $\begin{array}{l}\text { IAS and } \\
\text { EAS }\end{array}$ \\
\hline & $\begin{array}{c}\text { Internal sphincter } \\
\text { hemi-sphincterectomy }\end{array}$ & $6-8$ weeks & $\begin{array}{l}\text { Bohl et al., } 2017 \text { [55], Dadhich et al., } 2019 \\
\text { [56] }\end{array}$ & Rabbit, NHP & $\begin{array}{l}50 \% \text { excision of ventral portion } \\
\text { of anal sphincter }\end{array}$ & IAS \\
\hline
\end{tabular}




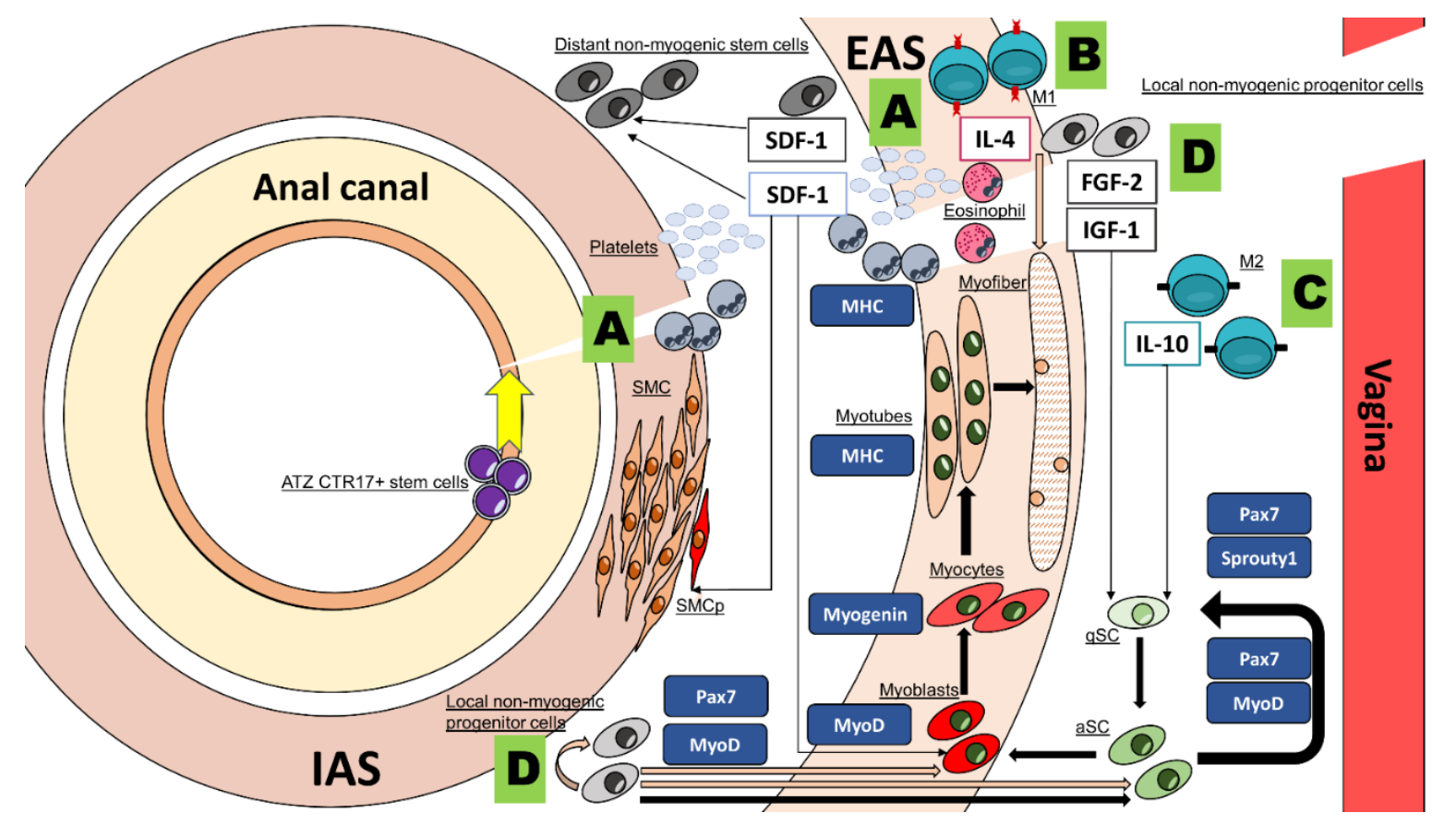

Figure 1. Schematic representation of events occurring after delivery-related acute anal sphincters injury [20,22]. (A) The tear will induce a phase of inflammation where polymorphonuclear cells are attracted in the first hour and are responsible to maintain the function of macrophages that will arrive later. At the same time, platelets recruitment following the rupture of small vessels induces the releasee of SDF-1 following their degranulation. SDF-1 is primordial for anal sphincter regeneration and acts by attracting non-resident progenitor cells, myoblasts and smooth-muscle progenitors to the wound and by promoting the survival, migration and proliferation of these cells. (B) Macrophages of M1 (CD68 ${ }^{+}$) polarity arrives after the polymorphonuclear cells and largely contribute to the acute inflammation phase. (C) During the healing phase, activated satellite cells contribute to new muscle formation (black arrows) and each step is characterized by a specific hallmark protein expression (blue boxes). Then, macrophage polarity switches to M2 (CD163 ${ }^{+}$) and they produce cytokines such as Il-10 helping proliferation and differentiation of satellite cells. (D) During the healing phase, different kinds of non-myogenic local progenitor cells are activated, and some of them, like the fibro-adipogenic progenitors, are conditioned by the presence of IL-4 secreted by eosinophils, with this pathway being necessary for skeletal muscle regeneration. Nonmyogenic local progenitor cells interplay indirectly by the production of cytokines like FGF-2 and IGF-1 but can also fuse (camel arrows) with other non-myogenic local progenitor cells, satellite cells, myoblasts or even myofibers, inducing hypertrophy. Finally, in case of damage to the rectal wall mucosa, local stem cells of the anal transition zone contribute to the reparation of the rectum and anal transition zone mucosa. qSC: Quiescent satellite cell, aSC: Activated satellite cell, SMC: Smooth muscle cell, pSMC: Progenitor smooth muscle cell. ATZ: Anal transition zone.

Progenitor cells produce cytokines like stromal-derived factor 1 (SDF-1) that are both chemoattractive for progenitor cells (including myoblasts and smooth muscle progenitor cells) but also contribute to cell proliferation, migration and survival [20,57,58]. SDF-1 seems to be a prominent cytokine for anal sphincter healing. Salcedo et al., reported a rapid local burst of SDF-1 and monocyte chemotactic protein-3 (MCP-3) expression in rats one hour after sphincter injury and up to 21 days after injury [59]. Moreover, an injection of plasmids with SDF-1 directly into EAS muscle or transplantation of SDF-1 transfected progenitor cells both improved continence in rodents after partial sphincterectomy with the same extend $[43,44]$.

In theory, progenitor cells could be transplanted soon after injury and this is considered to be the best option to maximize the effect of transplantation (Figure 2) [20]. Indeed, it is supposed that progenitor cells might increase the natural healing process notably through the local release of cytokines such as SDF-1 [20,59]. This strategy was evaluated in several preclinical studies where progenitor cells were either directly injected after injury with surgical 
reparation, or not, to mimic the situation of a direct repair of sphincters [26-33,40]. Of note, some authors delayed this intervention by $24 \mathrm{~h}[15,39,40,46]$. To the best of our knowledge, progenitor cells have never been injected in a patient with acute anal sphincter injury.
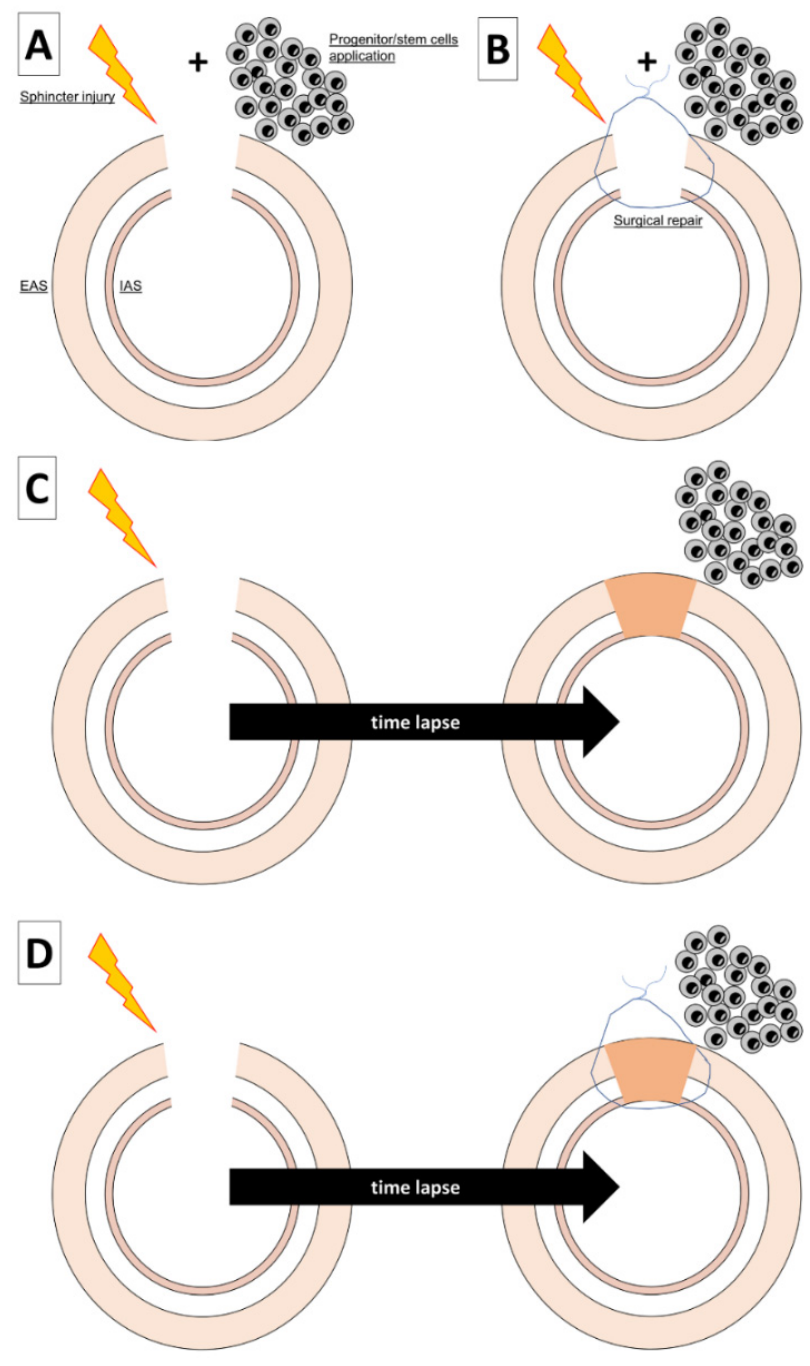

Figure 2. Cell therapy-based strategies for anal sphincter incontinence treatment. (A,B) Multipotent cells can be transplanted directly after injury with or without simultaneous reparation. (C) After injury, healing progresses but sometimes the muscle tissue is altered and responsible for ASI. Multipotent cells can be transplanted directly into the scar or in the neighborhood. (D) The best scenario could be to reinforce the surgical reparation of a sphincter defect with multipotent cells.

\subsection{Unrepaired Anal Sphincter Injury}

Most often, an anal sphincter tear is usually identified after delivery and surgically repaired [18]. Sometimes, the diagnosis can be missed, resulting in an occult anal sphincter injury [60]. As for an acute anal injury, little is known about the long-term healing and remodeling of damaged muscle, and an analogy can be made with the repair processes of skeletal and smooth muscles from other localizations (cf. Section 2.2). Probably, some unrepaired anal sphincter lesions could spontaneously heal. There exists evidence that a clear cut through anal sphincters in rats can heal spontaneously without inducing ASI [39,47]. As a result, almost all models of ASI in rats imply the partial resection of anal sphincters. In rat models where simple anal sphincters section were performed, acute and chronic inflammation was seen at the site of injury, characterized by neutrophils, monocytes macrophages infiltrations and fibrous tissue [28,30], disorganization of striated fibers of the EAS [43,45], but also mucin pool inclusions with histiocytes [42]. In rabbits, Rajasekaran investigated 
the effects of an EAS clear-cut section over time. The authors reported early collagen deposits from one week after injury, but also extensive fibrosis appearing three weeks after injury, at the site of myotomy but also beyond [61]. The presence of fibrosis was confirmed by other authors in rabbits [48,51]. In dogs, three weeks after IAS and EAS partial excision, Kang et al. reported focal interstitial inflammation, fibrosis and atrophy of smooth and striated muscles [54].

Anal sphincters encircle the anal canal, and the loss of this circular shape, as a result of injury, directly impairs the continence function [62]. However, during sphincter repair surgery, one can observe that the retracted muscle edges are held together with fibrous tissue, which bridges the defect [63]. Thus, unrepaired damage to IAS or EAS does not evolve into a hole in the sphincter ring (EAS and/or IAS), but rather into altered tissue, which fills the breach In rats, this tissue contained mast cells and other inflammatory cells [27]. To the best of our knowledge, the importance of this tissue was never investigated in humans but could be of importance, especially if the muscle gap is the target of cell therapy.

In the majority of preclinical studies, researchers investigated the direct injection of mesenchymal stem cells (MSC) in the area of muscle injury (Figure 2). This approach could be wrong as recent evidence stated that the transplantation of stem cells of mesenchymal origin during the late phase of healing can be deleterious and increase fibrosis [64]. Surprisingly, in the majority of fundamental studies modeling anal injury, the recovery time before cell therapy was very short (days) whereas after sphincter injury, ASI appears years or even decades after the initial trauma [65]. Therefore, future models should also consider a realistic healing time after anal sphincter injury before applying cell therapy. Indeed, trials with patients suffering from long-lasting ASI with EAS lesions have investigated the direct injection of multipotent cells into EAS lesions [66], muscle edges [66,67] or entire muscle [68,69].

Another strategy to treat patients with ASI is the transplantation of a biosphincter. Bitar's group, from the Wake Forest Institute for Regenerative Medicine, has been working for decades on the implantation of bioengineered anal sphincters composed of innervated smooth muscle cells (Table S2). The results are promising and the group recently implanted the construct in large animals, including non-human primates [55,56]. This strategy is interesting as it provides a complete and functional IAS substitute and might be part of a reconstruction strategy for patients in whom IAS has been totally or partially removed such as for ultra-low rectal cancer resections. However, IAS engineering has some hurdles to overcome. First, this approach uses IAS or digestive smooth muscle cells and intestinal neuronal cells. For translation to the clinic, tissue might be procured from organ donors, requiring further immunosuppression and exposing patients to its associated risks. Those risks need to be balanced with the fact that ASI is a non-life-threatening condition. Moreover, Araki et al., recently demonstrated the feasibility of anorectal transplantation in a dog model, with this approach being serious concurrent to allogenic biosphincters [70]. Further, the tissue culture of such constructs requires 6 to 8 weeks of culture, which increases the risk of microbial contamination. Finally, the cost of the creation of an organic construct seems to be higher than cell isolation and expansion.

\subsection{Secondary Repaired Anal Sphincter Injury}

Patients with visible EAS or IAS sphincter lesions are good candidates for surgical repair. Park's sphincteroplasty is the most common procedure where the two edges of the damaged sphincters are brought together with an overlapping suture $[5,63]$. Usually, the surrounding fibrous tissue, which also connects the retracted muscle, is not dissected as it offers a firm support for knotting [63]. To the best of our knowledge, the healing of such a delayed repair has never been investigated. Due to the poor long-term results of sphincteroplasty, the idea to strengthen the reparation with multipotent cells has emerged. As mentioned above, in preclinical studies, some authors injected multipotent cells during sphincter repair surgery but this was never done after secondary repair in animals [28,29,32,33,41]. However, Sarveazad et al. successfully and safely injected adipose tissue-derived multipotent cells after EAS sphincteroplasty in five women and two men (Table 2) [71]. 
Table 2. List of clinical studies on cell therapy for anal incontinence treatments. bn: billion, mio: million, FIQL: Fecal Incontinence Quality of Life.

\begin{tabular}{|c|c|c|c|c|c|c|c|c|c|}
\hline Publication. & Design & Women & Men & $\begin{array}{l}\text { Concerned } \\
\text { Sphincter }\end{array}$ & Cellular Therapy & Passages $n$ & $\begin{array}{l}\text { Number of } \\
\text { Injected Cell }\end{array}$ & Outcomes & Follow-Up \\
\hline $\begin{array}{l}\text { De la Portilla et al., } \\
\quad 2020 \text { [72] }\end{array}$ & $\begin{array}{l}\text { Randomized } \\
\text { controlled trial }\end{array}$ & 6 & 2 & EAS & $\begin{array}{l}\text { Autologous adipose tissue derived multipotent } \\
\text { cells injected into EAS lesion }\end{array}$ & Up to 7 & 4 bn & $\begin{array}{l}\text { Wexner incontinence score, } \\
\text { FIQL, safety and feasibility, } \\
\text { manometry }\end{array}$ & 12 months \\
\hline $\begin{array}{l}\text { Frudinger et al., } \\
\quad 2018[68]\end{array}$ & $\begin{array}{l}\text { Explorative } \\
\text { baseline } \\
\text { controlled study }\end{array}$ & 34 & 5 & EAS & $\begin{array}{l}\text { Anal electrical stimulation followed by } 12 \\
\text { injections of autologous myoblasts from } \\
\text { pectoralis muscle into the entire EAS. }\end{array}$ & 3 & 25 mio & $\begin{array}{l}\text { Wexner incontinence score and } \\
\text { FIQL score, anorectal } \\
\text { manometry }\end{array}$ & 12 months \\
\hline $\begin{array}{l}\text { Boyer et al., } 2018 \\
\text { [69] }\end{array}$ & $\begin{array}{l}\text { Randomized } \\
\text { controlled trial }\end{array}$ & 12 & 0 & EAS & $\begin{array}{l}\text { Autologous myoblasts derived from quadriceps } \\
\text { injected at } 8 \text { points into the EAS under endoanal } \\
\text { ultrasonography guindance }\end{array}$ & 3 & 0.2 to $2 \mathrm{bn}$ & Wexner incontinence score & 12 months \\
\hline $\begin{array}{l}\text { Sarvezaad et al., } \\
\quad 2017[71]\end{array}$ & $\begin{array}{l}\text { Randomized } \\
\text { controlled trial }\end{array}$ & 7 & 2 & EAS & $\begin{array}{l}\text { Allogenic hADSC injection along with external } \\
\text { sphincteroplasty }\end{array}$ & 5 & 6 mio & $\begin{array}{c}\text { Endoanal ultrasonography and } \\
\text { EMG }\end{array}$ & 2 months \\
\hline $\begin{array}{l}\text { Romaniszyn et al., } \\
\quad 2015[67]\end{array}$ & Pilot study & 10 & 1 & EAS & $\begin{array}{c}\text { Autologous myoblasts injected into EAS under } \\
\text { ultrasound guidance }\end{array}$ & 7-10 passages & 100 mio & $\begin{array}{l}\text { Anorectal manometry, EMG, } \\
\text { endoanal ultrasonography }\end{array}$ & 12 months \\
\hline $\begin{array}{l}\text { Frudinger et al., } \\
2010 / 2015[66,73]\end{array}$ & Pilot study & 10 & 0 & EAS & $\begin{array}{l}\text { Anal electrical stimulation followed by } 12-14 \\
\text { injections of autologous myoblasts from pectoralis } \\
\text { muscle into the defect and the edges of EAS }\end{array}$ & - & 20.16 mio & $\begin{array}{l}\text { Wexner incontinence score, } \\
\text { anorectal manometry } \\
\text { (contractile tone), endoanal } \\
\text { ultrasonography }\end{array}$ & 60 months \\
\hline
\end{tabular}




\subsection{Chronic Anal Sphincter Impairment}

In some patients with ASI, a clear injury event cannot be found, and patients have either weak anal sphincter tonus without an anomaly on imaging or hypotrophy of anal sphincters on imaging. This could be the result of aging, denervation or degenerative mechanisms inducing a chronic injury to the anal sphincters [47]. IAS is responsible for the anal sphincter basal tone and contributes to up to $85 \%$ of the pressure necessary to keep the anal canal closed [75]. Indeed, IAS basal tonus is maintained without neural stimulus by the high expression of proteins inducing contractility in the IAS smooth muscle cells [76,77]. A high content of smooth muscle actin and myosin isoforms has been reported in IAS [77-79], but spontaneous contraction property is driven by the continuous phosphorylation of myosin light chain by protein kinase $\mathrm{C}$ (PKC) and Rho kinase systems; indeed proteins of these cascades, such as PKC $\alpha$, RhoA, CPI-17 and HSP27 were prominent in human IAS smooth muscle cells compared to smooth muscle cells sampled from a human colon used as a control [79]. Specifically, it was demonstrated in humans that the RhoA/ROCK system is the main effector of the IAS basal tone and is constitutively activated by the renin-angiotensin system and arachidonic acid products [80]. On the other hand, IAS non-adrenergic non-cholinergic nerves negatively regulate the basal tone, essentially through nitric oxide (NO), which is the main neurotransmitter negatively affecting IAS [81]. Moreover, it was recently demonstrated in rats that RhoA/ROCK system proteins were the target of microRNA, which were reducing the IAS basal tone by a diminution of the expression of components necessary for signal transduction $[82,83]$. Particularly, micro-RNA-133a was increased with aging in rats and might partially explain the degeneration of IAS [82]. Other effects of aging, observed in colon smooth muscle cells, could also be present in IAS, including a diminution of RhoA translocation, a diminution in the association of the pairs actin/myosin and tropomyosin/HSP27 and a decrease in the phosphorylation of HSP27 [84]. These elements could partially explain the weakness of anal sphincters seen in older people.

Diabetes has been associated with ASI [85] and may affect anal sphincters from the cellular to the nervous level $[77,82,83]$. However, the precise mechanism of diabetes on anorectal function has been poorly investigated. At the cellular level, the expression of miRNA-133, linked to IAS degeneration, was also increased in diabetic rodents [82]. Diabetic neuropathy affects gastrointestinal motility [86] and measures of anal function in diabetic patients showed a reduction of maximal squeeze pressure (which is a reflection of EAS function) in diabetic patients compared to healthy controls [87]. Furthermore, patients suffering from inflammatory bowel disease are more prone to report ASI. There is probably an overlap between the alteration in bowel motility, the decrease in rectal compliance due to rectum inflammation and the sequel of repeated anal fistula surgery $[88,89]$. However, further investigation of muscle alteration during inflammatory bowel disease has never been carried out.

To date, there is unfortunately no model mimicking a degeneration of the muscles of EAS or IAS. Hosokawa et al. proposed a model of EAS and IAS injury using cardiotoxin but the injury was finally similar to sphincter resection [90]. This model was never used to assess cell therapy efficacity/efficiency.

\section{Multipotent Cell Origin and Isolation}

\subsection{Multipotent Cell Origins}

Multipotent cells proposed for ASI cell therapy can be derived from various tissues. The most frequent sites were skeletal muscle, bone marrow or adipose tissue. Cell preparations were either syngeneic or autologous, and allogeneic or xenogeneic transplantation was marginal (four preclinical studies and one clinical study). Cells from a muscular origin were used in the majority of the identified publications: In 17 studies, they originated from skeletal muscle or EAS $[32,33,36,37,49,50,52-54,66-69,73,74,91-93]$ and in 11 studies, from smooth muscle or IAS [56,79,94-102] (Table 3). Four out of six clinical trials used skeletal muscle multipotent cells whereas the other used adipose tissue multipotent cells $[66-69,74]$. Two in vivo publications reported the use of commercial H9c2 rat heart myoblasts [28,42]. 
Table 3. Characteristics of primary cells proposed for cell therapy of anal sphincter incontinence. MHC: Myosin heavy chain, Sma: $\alpha$-Smooth-muscle-actin, MyoG: Moygenin

\begin{tabular}{|c|c|c|c|c|c|c|c|c|c|}
\hline & Publication & Cells Origin & Species & $\begin{array}{c}\text { Surface } \\
\text { Antigens } \\
\text { Expressed } \\
\end{array}$ & $\begin{array}{c}\text { Surface } \\
\text { Antigens Not } \\
\text { Expressed }\end{array}$ & $\begin{array}{c}\text { GENE } \\
\text { Expression }\end{array}$ & $\begin{array}{c}\text { Intracellular } \\
\text { Protein } \\
\text { Expressed }\end{array}$ & $\begin{array}{c}\text { Intracellular } \\
\text { Protein Not } \\
\text { Expressed }\end{array}$ & $\begin{array}{l}\text { Differentiation } \\
\text { Test }\end{array}$ \\
\hline \multirow{13}{*}{$\begin{array}{c}\text { Muscle- } \\
\text { Dervied } \\
\text { Cells }\end{array}$} & Bisson et al., 2015 [36] & $\begin{array}{l}\text { Skeletal } \\
\text { muscle }\end{array}$ & Rat & CD56 & 1 & $\begin{array}{l}\text { DES, MYOD1, } \\
\text { MYF5, }\end{array}$ & 1 & - & - \\
\hline & $\begin{array}{l}\text { Lane et al. } 2013 \text { [32], Jacobs et al., } \\
2013 \text { [33], Craig et al., } 2010 \text { [92] }\end{array}$ & $\begin{array}{c}\text { Skeletal } \\
\text { muscle }\end{array}$ & Rat & - & - & - & - & - & - \\
\hline & Saihara et al., 2009 [91] & $\begin{array}{l}\text { Skeletal } \\
\text { muscle }\end{array}$ & Rat & - & - & - & - & - & Myotubes \\
\hline & Kang et al., 2008 [37] & $\begin{array}{l}\text { Skeletal } \\
\text { muscle }\end{array}$ & Rat & CD34 & CD45 & - & Desmin & - & - \\
\hline & Kajbafzadeh et al., 2016 [49] & $\begin{array}{l}\text { Skeletal } \\
\text { muscle }\end{array}$ & Rabbit & - & - & - & Pax7, Desmin & - & Myotubes \\
\hline & Elmi et al., 2014 [50] & $\begin{array}{l}\text { Skeletal } \\
\text { muscle }\end{array}$ & Rabbit & - & - & - & $\begin{array}{l}\text { Desmin, } \\
\text { MyoD }\end{array}$ & - & \\
\hline & $\begin{array}{c}\text { Oh et al., } 2015 \text { [52], Oh et al., } 2015 \\
\text { [53] }\end{array}$ & $\begin{array}{l}\text { Skeletal } \\
\text { muscle }\end{array}$ & Dog & - & - & - & Pax7, Sma & $\begin{array}{l}\text { MHC, } \\
\text { MyoG }\end{array}$ & Myotubes \\
\hline & Kang et al., 2013 [54] & $\begin{array}{l}\text { Skeletal } \\
\text { muscle }\end{array}$ & Dog & - & - & - & $\operatorname{Pax} 7$ & MHC & $\alpha$-SMA \\
\hline & $\begin{array}{l}\text { Frudinger et al., } 2015 \text { [66], } \\
\text { Frudinger et al., } 2018 \text { [68] }\end{array}$ & $\begin{array}{l}\text { Skeletal } \\
\text { muscle }\end{array}$ & Human & $\begin{array}{l}\text { SSEA3, SSEA4, } \\
\text { CD56, CD90 }\end{array}$ & 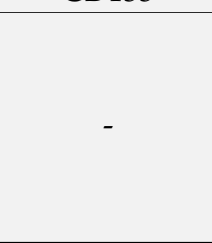 & $\begin{array}{c}\text { NANOG1, } \\
\text { NACAM1, } \\
\text { MYOD1, } \\
\text { PAX7, PAX3, } \\
\text { MYF5, DES, } \\
\text { MYOG }\end{array}$ & $\begin{array}{l}\text { Desmin, UTF1, } \\
\text { Pax7, Myf5 }\end{array}$ & - & Myotubes \\
\hline & Romaniszyn et al., 2015 [67] & $\begin{array}{l}\text { Skeletal } \\
\text { muscle }\end{array}$ & Human & CD56 & - & $\begin{array}{c}\text { DES, MYOD1, } \\
\text { MYOG }\end{array}$ & - & - & Myocyte \\
\hline & Romaniszyn et al., 2013 [74] & $\begin{array}{l}\text { Skeletal } \\
\text { muscle }\end{array}$ & Human & - & - & - & - & - & - \\
\hline & Son et al., $2019[93]$ & EAS & Human & CD34, NG2 & - & - & Pax7 & - & MyoG, MyHC \\
\hline & $\begin{array}{l}\text { Bohl et al., } 2017 \text { [102], Rego et al., } \\
2017 \text { [98] }\end{array}$ & $\begin{array}{l}\text { Smooth } \\
\text { muscle }\end{array}$ & Rabbit & & & & & & \\
\hline
\end{tabular}


Table 3. Cont.

\begin{tabular}{|c|c|c|c|c|c|c|c|c|c|}
\hline & Publication & Cells Origin & Species & $\begin{array}{c}\text { Surface } \\
\text { Antigens } \\
\text { Expressed }\end{array}$ & $\begin{array}{c}\text { Surface } \\
\text { Antigens Not } \\
\text { Expressed }\end{array}$ & $\begin{array}{c}\text { GENE } \\
\text { Expression }\end{array}$ & $\begin{array}{l}\text { Intracellular } \\
\text { Protein } \\
\text { Expressed }\end{array}$ & $\begin{array}{c}\text { Intracellular } \\
\text { Protein Not } \\
\text { Expressed }\end{array}$ & $\begin{array}{l}\text { Differentiation } \\
\text { Test }\end{array}$ \\
\hline & $\begin{array}{l}\text { Raghavan et al., } 2010 \text { [99], Hashish } \\
\text { et al., } 2010 \text { [100], Miyasaka et al., } \\
\text { 2011 [101] }\end{array}$ & IAS & Mouse & - & - & - & - & - & - \\
\hline & $\begin{array}{c}\text { Zakhem et al., } 2015 \text { [97], Rego } \\
\text { et al., } 2017 \text { [98] }\end{array}$ & IAS & Rabbit & - & - & - & - & - & - \\
\hline & Dadhich et al., 2019 [56] & IAS & NHP & - & - & SMTN & - & $\begin{array}{l}\text { Sma, and } \\
\text { smoothelin }\end{array}$ & - \\
\hline & Gilmont et al., 2014 [95] & IAS & Human & - & - & - & - & - & - \\
\hline & Singh and Rattan, 2012 [94] & IAS & Human & - & - & - & - & - & - \\
\hline & $\begin{array}{c}\text { Raghavan et al., } 2014 \text { [96], Somara } \\
\text { et al., } 2009 \text { [79] }\end{array}$ & IAS & Human & - & - & - & - & - & - \\
\hline \multirow{7}{*}{$\begin{array}{l}\text { Bone Marrow- } \\
\text { Dervied } \\
\text { Cells }\end{array}$} & Li et al., 2018 [46] & $\begin{array}{l}\text { Bone } \\
\text { marrow }\end{array}$ & Rat & - & CD34, CD45 & - & - & - & - \\
\hline & Ding et al., 2016 [41] & $\begin{array}{c}\text { Bone } \\
\text { marrow, } \\
\text { transfected } \\
\text { with } \\
\text { galectin-1 }\end{array}$ & Rat & CD90 & CD45 & - & - & - & - \\
\hline & Sun et al., 2017 [44] & $\begin{array}{l}\text { Bone } \\
\text { marrow }\end{array}$ & Rat & - & - & - & - & - & - \\
\hline & $\begin{array}{c}\text { Mazzanti et al., } 2016 \text { [27], Lorenzi } \\
\text { et al., } 2008 \text { [26] }\end{array}$ & $\begin{array}{l}\text { Bone } \\
\text { marrow }\end{array}$ & Rat & $\begin{array}{c}\text { CD44, CD54, } \\
\text { CD73, CD90, } \\
\text { CD106 }\end{array}$ & $\begin{array}{c}\text { CD11b, } \\
\text { CD11c, CD45 }\end{array}$ & - & - & - & $\begin{array}{l}\text { Osteogenic and } \\
\text { adipogenic }\end{array}$ \\
\hline & $\begin{array}{l}\text { Salcedo et al., } 2014 \text { [39], Salcedo } \\
\text { et al., } 2013 \text { [15] }\end{array}$ & $\begin{array}{c}\text { Bone } \\
\text { marrow }\end{array}$ & Rat & 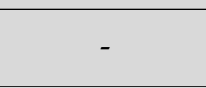 & CD34, CD45 & - & - & - & - \\
\hline & Pathi et al., 2012 [30] & $\begin{array}{c}\text { Bone } \\
\text { marrow }\end{array}$ & Rat & - & - & - & - & - & - \\
\hline & Aghaee-Afshar et al., 2009 [48] & $\begin{array}{l}\text { Bone } \\
\text { marrow }\end{array}$ & Rabbit & - & - & - & - & - & - \\
\hline
\end{tabular}


Table 3. Cont.

\begin{tabular}{|c|c|c|c|c|c|c|c|c|c|}
\hline & Publication & Cells Origin & Species & $\begin{array}{c}\text { Surface } \\
\text { Antigens } \\
\text { Expressed }\end{array}$ & $\begin{array}{c}\text { Surface } \\
\text { Antigens Not } \\
\text { Expressed }\end{array}$ & $\begin{array}{c}\text { GENE } \\
\text { Expression }\end{array}$ & $\begin{array}{l}\text { Intracellular } \\
\text { Protein } \\
\text { Expressed }\end{array}$ & $\begin{array}{c}\text { Intracellular } \\
\text { Protein Not } \\
\text { Expressed }\end{array}$ & $\begin{array}{c}\text { Differentiation } \\
\text { Test }\end{array}$ \\
\hline \multirow{5}{*}{$\begin{array}{c}\text { Adipose } \\
\text { Tissue-Dervied } \\
\text { Cells }\end{array}$} & Trébol et al., 2018 [35] & $\begin{array}{l}\text { Adipose } \\
\text { tissue }\end{array}$ & Rat & CD29, CD90 & CD11n, CD45 & - & - & - & - \\
\hline & Inoue et al., 2018 [34] & $\begin{array}{l}\text { Adipose } \\
\text { tissue }\end{array}$ & Rat & CD90 & CD31, CD45 & - & - & - & $\begin{array}{l}\text { Adipogenic and } \\
\text { myogenic }\end{array}$ \\
\hline & Sarveazad et al., 2019 [38] & $\begin{array}{l}\text { Adipose } \\
\text { tissue }\end{array}$ & Human & $\begin{array}{c}\text { CD29, CD73, } \\
\text { CD105 }\end{array}$ & CD34, CD45 & & & & \\
\hline & Sarveazad et al., 2017 [71] & $\begin{array}{l}\text { Adipose } \\
\text { tissue }\end{array}$ & Human & $\begin{array}{c}\text { CD44, CD73, } \\
\text { CD90 }\end{array}$ & $\mathrm{CD} 31, \mathrm{CD} 45$ & - & - & - & - \\
\hline & Kuismanen et al., 2018 [31] & $\begin{array}{l}\text { Adipose } \\
\text { tissue }\end{array}$ & Human & $\begin{array}{l}\text { CD73, CD90, } \\
\text { CD105 }\end{array}$ & $\begin{array}{c}\text { CD14, CD19, } \\
\text { CD34, } \\
\text { CD45RO, } \\
\text { CD54, } \\
\text { HLA-DR }\end{array}$ & - & - & - & - \\
\hline \multirow{5}{*}{$\begin{array}{c}\text { Neural } \\
\text { Tissue-Derived } \\
\text { Cells }\end{array}$} & Bohl et al., 2017 [102] & $\begin{array}{l}\text { Enteric } \\
\text { Neural } \\
\text { System }\end{array}$ & Rabbit & - & 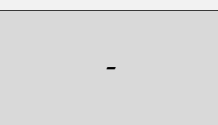 & - & - & - & - \\
\hline & Rego et al., 2017 [97] & $\begin{array}{c}\text { Enteric } \\
\text { neuronal } \\
\text { system }\end{array}$ & Rabbit & - & - & - & - & - & Neurospheres \\
\hline & Dadhich et al., 2019 [56] & $\begin{array}{c}\text { Enteric } \\
\text { neuronal } \\
\text { system }\end{array}$ & NHP & P75 (NTR) & & & & $\begin{array}{l}\text { smoothelin, } \\
\text { oct } 4\end{array}$ & \\
\hline & Gilmont et al., 2014 [95] & $\begin{array}{c}\text { Enteric } \\
\text { neuronal } \\
\text { system }\end{array}$ & Human & P75 (NTR) & - & - & - & - & Neurospheres \\
\hline & $\begin{array}{l}\text { Raghavan et al., } 2014 \text { [96], } \\
\text { Raghavan et al., } 2011 \text { [103] }\end{array}$ & $\begin{array}{c}\text { Enteric } \\
\text { neuronal } \\
\text { system }\end{array}$ & Human & - & - & - & - & - & - \\
\hline Miscellaneous & Aghaee-Afshar et al., 2009 [48] & $\begin{array}{c}\text { Umbilical } \\
\text { cord matrix }\end{array}$ & Human & - & - & - & - & - & - \\
\hline
\end{tabular}


Cells of bone marrow origin were used in 10 studies [15,26,27,30,39-41,43,46,48] and only six tested cells originating from adipose tissue $[31,34,35,38,71,72]$. Neural cells were used for bioengineered constructs in eight publications [92-99,102,103]. Bioengineered constructs used smooth muscle seeded with neuronal cells from different origins. Finally, only one publication evaluated the potential of human umbilical cord matrix cells [48].

Skeletal muscle-derived cells seem to be an interesting source for ASI therapy. Different multipotent cells can be extracted from skeletal muscle: Satellite cells and other resident multipotent cells, the former having the ability to become new satellite cells or myoblasts, the precursors of myocytes (Figure 1) [104]. Thurner et al. demonstrated that smooth muscle cells can eventually be derived from myogenic progenitors [105]. The function of other muscle resident multipotent cells is not completely understood and this category encompasses different kinds of multipotent cells such as adult pericytes, $\mathrm{PW} 1^{+}$interstitial cells and fibro-adipogenic progenitors [106].

Satellite cells have the ability to reform muscle fiber [104] and have been proposed to treat conditions such as Duchenne disease [107], coronary artery disease [108] and also urinary incontinence [109]. It is supposed that skeletal muscle multipotent cells differentiated into new myocyte and could resupply EAS with new fibers (Figure 1). Indeed, the apparition of new fibers in EAS and the expression of muscle proteins have been observed by several authors $[36,50,52,53,91,92]$. However, the appearance of new muscle fibers does not necessarily indicate that anal function is improved. In this regard, several in vivo studies $[28,37,54]$ using myogenic cells were inconclusive concerning anal function recovery despite cell engraftment confirmation.

Cells derived from adipose tissue constitute an interesting option, as subcutaneous fat tissue is easily accessible. The cells used in the reported studies [31,34,35,71] had the characteristics of MSC including the ability to differentiate into various tissues. MSC are multipotent cells that have been evaluated over the last years to treat various conditions including spinal cord injury, corneal or uvea injury, lung injury, cerebral injury, colitis, alopecia, muscular degenerative disease, myocardial infarction, liver injury, multiple sclerosis, Parkinson disease, cancer and to improve wound healing [110]. Indeed, allogeneic adipose tissue MSCs became popular because of their poor immunogenicity and their availability after liposuction surgery. However, recent evidence demonstrated the development of donor-specific antibodies, and MSC rejection has been documented. Besides MSC's ability to differentiate into various cells, their paracrine action have been proposed to mediate most of their effects $[110,111]$. MSC produce a large amount of growth factors and extracellular vesicles [112]. Strategies using encapsulated MSC conserve the effects of MSC, notably on liver fibrosis, confirming the efficacy of paracrine action and treatment [113]. Thus, MSC can be seen as in situ bioreactors delivering growth factors to neighboring cells. MSC have the ability to induce smooth muscle regeneration from the gut and the bladder $[114,115]$ and also skeletal muscle regeneration $[116,117]$. Thus, MSC therapy may promote the healing and regeneration of both IAS and EAS.

\subsection{Methods for Multipotent Cell Isolation and Processing}

Stem cell and progenitor cells were retrieved from rats, mice, rabbits, non-human primate or humans (Table S1). Different harvest methods were used according to the origin of the collected tissue, but protocols were similar to existing standard, with the first step of washing and decontamination followed by the digestion of tissue and, finally, the purification of the cell suspension before plating. In the majority of studies, isolation procedures were sufficiently detailed, but some studies lack essential information concerning the isolation procedures. Skeletal muscle was digested with collagenase I $[49,50,98]$, collagenase type II [93], collagenase type IV [92] collagenase type XI [37,54,91], collagenase NB6 [69], trypsin [91] and and/or dispase II [52,53,91]. Intestinal smooth muscle was digested using collagenase I [94] or collagenase II [79,93,95,97,99-103,118]. Enteric neurons were isolated after the digestion of tissue with collagenase II and dispase II [15,95,97,102,103]. For bone-marrow MSC, bones were flushed, and bone marrow collected, washed, sometimes 
fractionated with density gradient and plated [27,39,40,43-46]. For fat multipotent cells, adipose tissue was digested with collagenase I [31,34,35,71].

\subsection{Methods for Multipotent Cell Characterization}

The characterization of isolated multipotent cells is mandatory for reproducibility but also for quality purpose, especially when a clinical application for ASI treatment is foreseen. Among publications using muscle multipotent cells, only 13 studies reported or referred to a proper characterization of the cells and were heterogeneous for markers (Table 3) $[36,37,49,50,52-54,56,66-69,93]$. Indeed, international criteria for MSC definition were not always applied/fulfilled/verified [119].

Cells of bone marrow origin were used in nine publications [15,26,27,30,39,41,43,46,48] and were well characterized only in seven $[15,26,27,39,41,43,46]$. Cells originating from adipose tissue were more often precisely characterized and were at least $\mathrm{CD} 90^{+}$and CD45 $^{-}[31,34,35,38,71]$. Satellite cells have typical features such as the expression of the transcription factor PAX7 (Figure 1) [104] but there is currently a lack of standardization in the nomenclature and characterization of other myogenic cells [120]. Thus, multipotent cells from a skeletal origin were widely used to treat in vivo models of ASI, but their efficacy, as well as their identification, remained elusive. As the cell types used were insufficiently characterized, it cannot be excluded that the beneficial effect on ASI was partially mediated by co-isolated contaminant multipotent cells from connective tissue. Moreover, if we assume that satellite cells were responsible for the positive effects of skeletal muscle cell preparation on ASI, this effect was thus induced by their action on the skeletal muscle of EAS and not on the smooth muscle of IAS.

\section{Multipotent Cell Transplantation}

\subsection{Practical Considerations}

Before transplantation, cells were cultivated on plastic dishes and the number of passages before injection in the identified clinical trials ranged from three to ten. The number of injected cells, clearly reported by identified in vivo reports, ranged from 10,000 up to 90 million. In clinical trials, this number ranged from 200,000 up to 2 billion. However, the minimum number of cells required to obtain a beneficial effect on ASI remains elusive and only a few authors performed a real titration $[36,92]$. Thus, an excess of cells was used to compensate stem cell and progenitor cell death. Transplanted cell survival is a main concern in the field of cell therapy and it can be impaired by several factors related to the mechanical force applied during cell application, detachment from cell substrate and receiving site with inflammation and/or local hypoxia [121]. Indeed, forces generated during injection with a syringe needle are sufficient to induce up to $40 \%$ of cell death [121]. Thus, strategies have been developed to improve cell engraftment and transplantation success.

\subsection{Adjuvant Therapy}

As a strategy to limit cellular stress due to transplantation, some authors proposed to protect cells with biomaterials [52-54,110]. Indeed, it is known that preserving cellextracellular substrate interactions can limit stem cell apoptosis [121]. Biomaterials were typically scaffolds of decellularized matrices or hydrogel polymers [31,41-43,51]. Deserving the same purpose, multipotent cells were also transplanted as sheets of cells instead of individual cells [34]. Alternatively, Trébol et al. seeded suture thread with MSC to be used for sphincter reconstruction [35] whereas Ding et al. reinforced reconstruction with a patch of an acellular dermal matrix also seeded with MSC [41].

As mentioned earlier, in some studies, authors performed immediate injection of cells along with sphincter repair, confronting cells with an acute inflammatory environment that presumably precludes cell survival [121]. On the other hand, inflammation can also enhance cell settling and homing, and the injection of myoblasts in healthy regions of EAS did not restore continence compared to the injection of cells into injured parts [36,121]. Other known strategies to improve cell survival implicated pre-conditioning of cells with 
either thermal preconditioning, hypoxic preconditioning, acidic preconditioning or nutrient deprivation preconditioning [121]. The goal of these strategies is to induce anti-apoptotic protein expression [121]. Injection sites were also prepared, and electrical stimulation was used in two in vivo studies $[45,46]$ and two clinical studies to promote the homing of cells into anal sphincters $[66,68]$. Moreover, laser beam stimulation along with cell therapy was used in one study to promote muscle proliferation [38].

Further, growth factors (SDF-1, FGF) described to promote stem cell implantation were delivered in situ by bioscaffolds or through osmotic pumps $[44,45,99,100,103]$. Two studies transfected cells with SDF-1 plasmids before implantation $[43,44]$. As an alternative to the use of growth factors, platelet rich plasma, which is known to contain numerous growth factors, might be transplanted conjointly with stem cells [122].

\subsection{Measure of Outcomes and Results}

For in vitro studies, physiological functional evaluation was carried out in almost all identified studies to assess the contractility potential of constructed sphincters. For in vivo studies, outcomes were highly variable: The most common methods for outcome assessment were histology, anorectal manometry, physiological functionality evaluation and electromyography or electrophysiology. Some authors tracked cells using magnetic resonance imaging [50] or labeled them with fluorescent proteins (GFP) [91].

The determination of the outcome in a clinical study on anal incontinence is challenging. Different definitions of ASI exists, including incontinence to gases or not [1]. Further, in order to be comparable to the literature, authors are choosing outcomes that appear to be a gold standard in the medical literature. In almost all published clinical studies, one incontinence score was used as the primary outcome. However, a recent analysis of different incontinence scores pointed out that no single score reaches relevant psychometric soundness and recommended the use of at least two scores to evaluate ASI [122]. However, the utilization of objective outcomes may be more reliable such as high-resolution anal manometry or contact EMG (For e.g., MAPLe ${ }^{\circledR}$ device, Medtronic, Dublin, Ireland [123]).

\subsection{Results}

A review of the literature identified a total of 52 original publications. Seven publications reported in vitro results (Table S2) $[79,93-95,97,98]$, with six on bioengineered constructs among them $[79,94,95,97,98]$. One publication reported the isolation of cells from human IAS and EAS and assessed their viability [93]. In vivo experiments were reported in 38 publications (Table S1) $[15,26,27,29-43,45,46,48-54,56,91,92,96,99-103]$, including five articles on heterotopic sphincter bioconstruct implantation [96,99-101,103]. Seven human studies were identified (Table 2) $[66,68,69,71,72,74]$, including three randomized controlled trials $[69,71,72]$ and one case report [74]. A total of 83 patients received cell therapy for ASI treatment.

Almost all patients included in clinical trials exhibited EAS injury. Four out of seven studies used the Wexner score as the primary outcome. The FIQL score was used in two studies. Other variables measured were anorectal manometry (5/7), endoanal ultrasonography (3/7) and electromyography (EMG) (3/7). The longest follow-up was reported by the group of Frudinger et al. who injected autologous myoblasts into EAS in 10 voluntary women with EAS defect or atrophy [66]. After a follow-up of 5 years, the mean Wexner score decreased from 15.3 (SD-2.4) before intervention to 0.7 (SD 1.3) $(p>0.001)$. In addition, anal manometry demonstrated an improvement of median resting and squeeze pressures (20 (IQR 17-28) to 32 (25-43) and 23 (IQR 20-34) to 33 (IQR 31-66), respectively). The same group started a second trial including 34 females and 5 males and found a reduction of Wexner score of -16.2 (SD-3.66) for women and -18.8 (SD-1.30) for male at one year. These results were better than sphincteroplasty, which typically induces a long-term reduction of -1 to -5.2 of median/mean Wexner score (mean follow-up between seven and eight years) $[124,125]$. In a similar study (muscle tissue-derived multipotent cells injected into EAS), Boyer et al. reported a reduction of median Wexner score of -6.4 (range -12 to 2$)$ $(p=0.006)$ for the intervention group and a reduction of -1 (range -8 to 6$)(p=0.35)$ for 
the placebo [69]. However, using adipose tissue-derived multipotent cells in a randomized triple blinded placebo-controlled trial, De la Portilla et al. failed to demonstrate any effect on Wexner score of cell transplantation into EAS defect [72]. Globally, all seven reports described encouraging results regarding at least one of the measured outcomes (which was not necessary the primary outcome).

Until now, in vivo experiments have demonstrated a relative oncological safety of such a strategy. One in vivo study described focal cell growth at the injection site but without malignant characteristics [33]. Recent evidence confirmed that pure stem cell cultures, particularly MSC, did not develop malignant cells [126,127]. However, MSC have opposite effects on tumor cells and can promote or suppress tumor growth in vitro and in vivo [128]. Published clinical trials, which used either skeletal muscle tissue or adipose tissue multipotent cells, demonstrated that the procedures were safe.

\section{Conclusions}

Preclinical and clinical studies have demonstrated the safety of multipotent cell utilization for ASI. Published clinical studies have shown promising results, but only three of them were controlled with placebo injection $[69,71,72]$. These controlled studies had relative short followups considering that ASI is a disease evolving over time. Thus, all the presented strategies for cell therapy in the context of ASI deserve further randomized controlled trials with improved methodology regarding outcome measurement and follow-up.

The ideal therapy for ASI should be cost-effective with a long-lasting effect. Apart from research and development costs, good manufacturing practices, GMP certifications and implementation charges, routine use of cell therapy appears to be highly costly [129]. Trébol et al. estimated the maximal production costs in Spain to be 7400 USD for 40 million autologous fat-derived cells or $8500 €$ for 100 million allogeneic fat-derived cells [128]. In our hospital, the cost for a sphincteroplasty, with a typical length of stay of two days, is 5000 USD. Recently, Gräs et al. proposed a cost-effective alternative to cell transplantation for anal sphincter regeneration. Following promising results for urinary incontinence, the authors discussed the possibility to inject fragmented muscle fibers, instead of expanded cells, into injured anal sphincters [120].

After transplantation, progenitor cells and stem cells might act by paracrine effects and/or by differentiation into functional muscular cells. It should be pointed out that the exact underlying mechanism remains poorly understood, and that basic research on this topic is still required to understand which factors and conditions are leading to cell engraftment, differentiation and finally tissue regeneration [130,131].

Moreover, the natural history of sphincter lesion/repaired sphincter healing should be better understood in order to select appropriate cell preparations and transplantation techniques. Some groups reported a different approach, considering the use of cell therapy as an add-on to sphincter repair, either directly after lesion, to simulate the primary repair of an acute obstetrical tear or at distance [26-33]. Thus, it remains to be determined how stem cells and progenitor cells should be used for ASI: As a substitution to surgery or along with surgery.

Supplementary Materials: The following are available online at https:/ /www.mdpi.com/article/10.3 390/cells10082086/s1, Table S1 S1: List and description of identified in vivo publications investigating cell therapy for the treatment of anal sphincter incontinence, Table S2: List of in vitro publications.

Author Contributions: Conceptualization, A.B., B.R. and J.M.; methodology, A.B. and J.M.; software, A.B.; validation, A.B. and J.M.; resources, A.B., L.H.B., E.L., C.G.-G. and C.T.; writing-original draft preparation, A.B., J.M, R.P.H.M. and C.G.-G.; writing-review and editing, A.B., J.M., R.P.H.M., E.L., N.C.B., B.R., C.T., L.H.B., C.G.-G. and F.R.; visualization, A.B.; supervision, L.H.B., C.T., C.T. and F.R.; project administration, A.B.; funding acquisition, A.B., F.R. and C.T. All authors have read and agreed to the published version of the manuscript.

Funding: This research was funded by University Hospital of Geneva "Projet Recherche\&Développement", PRD 19-I-2020. 
Institutional Review Board Statement: Not applicable.

Informed Consent Statement: Not applicable.

Conflicts of Interest: The authors declare no conflict of interest. The funders had no role in the design of the study; in the collection, analyses, or interpretation of data; in the writing of the manuscript, or in the decision to publish the results.

\section{References}

1. Chatoor, D.R.; Taylor, S.J.; Cohen, C.R.G.; Emmanuel, A.V. Faecal Incontinence. Br. J. Surg. 2007, 94, 134-144. [CrossRef]

2. Meyer, I.; Richter, H.E. Impact of Fecal Incontinence and Its Treatment on Quality of Life in Women. Women's Health 2015, 11, 225-238. [CrossRef] [PubMed]

3. Williams, K.S.; Shalom, D.F.; Winkler, H.A. Faecal incontinence: A narrative review of clinic-based management for the general gynaecologist. J. Obstet. Gynaecol. 2017, 38, 1-9. [CrossRef]

4. Nandivada, P.; Nagle, D. Surgical therapies for fecal incontinence. Curr. Opin. Gastroenterol. 2014, 30, 69-74. [CrossRef] [PubMed]

5. Wexner, S.D.; Bleier, J. Current surgical strategies to treat fecal incontinence. Expert Rev. Gastroenterol. Hepatol. 2015, 9, 1-13. [CrossRef]

6. Zorcolo, L.; Covotta, L.; Bartolo, D.C.C. Outcome of Anterior Sphincter Repair for Obstetric Injury: Comparison of Early and Late Results. Dis. Colon Rectum 2005, 48, 524-531. [CrossRef] [PubMed]

7. Gronewold, M.; Kroencke, T.; Hagedorn, A.; Tunn, R.; Gauruder-Burmester, A. External anal sphincter repair using the overlapping technique in patients with anal incontinence and concomitant pudendal nerve damage. Zent. Chir. 2008, 133, 129-134. [CrossRef] [PubMed]

8. Demirbas, S.; Atay, V.; Sucullu, I.; Filiz, A.I. Overlapping Repair in Patients with Anal Sphincter Injury. Med. Princ. Pract. 2007, 17, 56-60. [CrossRef]

9. Brown, S.R.; Wadhawan, H.; Nelson, R.L. Surgery for faecal incontinence in adults. Cochrane Database Syst. Rev. 2013, 2013, CD001757. [CrossRef]

10. Zutshi, M.; Hull, T.; Gurland, B. Anal encirclement with sphincter repair (AESR procedure) using a biological graft for anal sphincter damage involving the entire circumference. Color. Dis. 2012, 14, 592-595. [CrossRef]

11. De La Portilla, F. Internal anal sphincter augmentation and substitution. Gastroenterol. Rep. 2014, 2, 106-111. [CrossRef]

12. Alam, N.N.; Narang, S.K.; Köckerling, F.; Daniels, I.R.; Smart, N. Anal Sphincter Augmentation Using Biological Material. Front. Surg. 2015, 2. [CrossRef]

13. Rao, S.S. Pathophysiology of adult fecal incontinence. Gastroenterology 2004, 126, S14-S22. [CrossRef] [PubMed]

14. LaCross, A.; Groff, M.; Smaldone, A. Obstetric Anal Sphincter Injury and Anal Incontinence Following Vaginal Birth: A Systematic Review and Meta-Analysis. J. Midwifery Women's Health 2015, 60, 37-47. [CrossRef] [PubMed]

15. Salcedo, L.; Mayorga, M.; Damaser, M.; Balog, B.; Butler, R.; Penn, M.; Zutshi, M. Mesenchymal stem cells can improve anal pressures after anal sphincter injury. Stem Cell Res. 2013, 10, 95-102. [CrossRef] [PubMed]

16. Healy, C.F.; O'Herlihy, C.; O'Brien, C.; O'Connell, P.R.; Jones, J. Experimental Models of Neuropathic Fecal Incontinence: An Animal Model of Childbirth Injury to the Pudendal Nerve and External Anal Sphincter. Dis. Colon Rectum 2008, 51, 1619-1626. [CrossRef]

17. Wai, C.Y.; Rahn, D.D.; White, A.B.; Word, R.A. Recovery of External Anal Sphincter Contractile Function After Prolonged Vaginal Distention or Sphincter Transection in an Animal Model. Obstet. Gynecol. 2008, 111, 1426-1434. [CrossRef]

18. Meister, M.R.; Rosenbloom, J.; Lowder, J.L.; Cahill, A.G. Techniques for Repair of Obstetric Anal Sphincter Injuries. Obstet. Gynecol. Surv. 2018, 73, 33-39. [CrossRef] [PubMed]

19. Mitoyan, L.; Chevrier, V.; Hernandez-Vargas, H.; Ollivier, A.; Homayed, Z.; Pannequin, J.; Poizat, F.; De Biasi-Cador, C.; Charafe-Jauffret, E.; Ginestier, C.; et al. A stem cell population at the anorectal junction maintains homeostasis and participates in tissue regeneration. Nat. Commun. 2021, 12, 1-13. [CrossRef]

20. Plair, A.; Bennington, J.; Williams, J.K.; Parker-Autry, C.; Matthews, C.A.; Badlani, G. Regenerative medicine for anal incontinence: A review of regenerative therapies beyond cells. Int. Urogynecol. J. 2020, 1-11. [CrossRef]

21. Sass, A.; Fuchs, M.; Pumberger, M.; Geissler, S.; Duda, G.N.; Perka, C.; Schmidt-Bleek, K. Immunology Guides Skeletal Muscle Regeneration. Int. J. Mol. Sci. 2018, 19, 835. [CrossRef]

22. Schmidt, M.; Schüler, S.C.; Hüttner, S.S.; Von Eyss, B.; Von Maltzahn, J. Adult stem cells at work: Regenerating skeletal muscle. Cell. Mol. Life Sci. 2019, 76, 2559-2570. [CrossRef]

23. Yin, H.; Price, F.; Rudnicki, M. Satellite Cells and the Muscle Stem Cell Niche. Physiol. Rev. 2013, 93, 23-67. [CrossRef]

24. Dumont, N.A.; Wang, Y.X.; Rudnicki, M.A. Intrinsic and extrinsic mechanisms regulating satellite cell function. Development 2015, 142, 1572-1581. [CrossRef] [PubMed]

25. Chellini, F.; Tani, A.; Zecchi-Orlandini, S.; Sassoli, C. Influence of Platelet-Rich and Platelet-Poor Plasma on endogenous mechanisms of skeletal muscle repair/regeneration. Int. J. Mol. Sci. 2019, 20, 683. [CrossRef]

26. Lorenzi, B.; Pessina, F.; Lorenzoni, P.; Urbani, S.; Vernillo, R.; Sgaragli, G.; Gerli, R.; Mazzanti, B.; Bosi, A.; Saccardi, R.; et al. Treatment of Experimental Injury of Anal Sphincters with Primary Surgical Repair and Injection of Bone Marrow-Derived Mesenchymal Stem Cells. Dis. Colon Rectum 2008, 51, 411-420. [CrossRef] [PubMed] 
27. Brzoska, E.; Kowalewska, M.; Markowska-Zagrajek, A.; Kowalski, K.; Archacka, K.; Zimowska, M.; Grabowska, I.; Czerwinska, A.M.; Czarnecka-Góra, M.; Stremińska, W.; et al. Sdf-1 (CXCL12) improves skeletal muscle regeneration via the mobilisation of Cxcr4 and CD34 expressing cells. Biol. Cell 2012, 104, 722-737. [CrossRef]

28. Chatterjee, M.; Gawaz, M. Platelet-derived CXCL12 (SDF-1 $\alpha$ ): Basic mechanisms and clinical implications. J. Thromb. Haemost. 2013, 11, 1954-1967. [CrossRef]

29. Salcedo, L.; Sopko, N.; Jiang, H.-H.; Damaser, M.; Penn, M.; Zutshi, M. Chemokine upregulation in response to anal sphincter and pudendal nerve injury: Potential signals for stem cell homing. Int. J. Color. Dis. 2011, 26, 1577-1581. [CrossRef] [PubMed]

30. Sun, L.; Kuang, M.; Penn, M.; Damaser, M.S.; Zutshi, M. Stromal Cell-Derived Factor 1 Plasmid Regenerates Both Smooth and Skeletal Muscle After Anal Sphincter Injury in the Long Term. Dis. Colon Rectum 2017, 60, 1320-1328. [CrossRef] [PubMed]

31. Sun, L.; Xie, Z.; Kuang, M.; Penn, M.; Damaser, M.S.; Zutshi, M. Regenerating the Anal Sphincter: Cytokines, Stem Cells, or Both? Dis. Colon Rectum 2017, 60, 416-425. [CrossRef] [PubMed]

32. White, A.B.; Keller, P.W.; Acevedo, J.F.; Word, R.A.; Wai, C.Y. Effect of Myogenic Stem Cells on Contractile Properties of the Repaired and Unrepaired Transected External Anal Sphincter in an Animal Model. Obstet. Gynecol. 2010, 115, 815-823. [CrossRef]

33. Pathi, S.D.; Acevedo, J.F.; Keller, P.W.; Kishore, A.H.; Miller, R.T.; Wai, C.Y.; Word, R.A. Recovery of the Injured External Anal Sphincter After Injection of Local or Intravenous Mesenchymal Stem Cells. Obstet. Gynecol. 2012, 119, 134-144. [CrossRef] [PubMed]

34. Jacobs, S.A.; Lane, F.L.; Pham, Q.-A.; Nistor, G.; Robles, R.; Chua, C.; Boubion, B.; Osann, K.; Keirstead, H. Safety Assessment of Myogenic Stem Cell Transplantation and Resulting Tumor Formation. Female Pelvic Med. Reconstr. Surg. 2013, 19, 362-368. [CrossRef]

35. Lane, F.L.; Jacobs, S.A.; Craig, J.B.; Nistor, G.; Markle, D.; Noblett, K.L.; Osann, K.; Keirstead, H. In Vivo Recovery of the Injured Anal Sphincter After Repair and Injection of Myogenic Stem Cells: An Experimental Model. Dis. Colon Rectum 2013, 56, 1290-1297. [CrossRef] [PubMed]

36. Fitzwater, J.L.; Grande, K.B.; Sailors, J.L.; Acevedo, J.F.; Word, R.A.; Wai, C.Y. Effect of myogenic stem cells on the integrity and histomorphology of repaired transected external anal sphincter. Int. Urogynecol. J. 2014, 26, 251-256. [CrossRef]

37. Mazzanti, B.; Lorenzi, B.; Borghini, A.; Boieri, M.; Ballerini, L.; Saccardi, R.; Weber, E.; Pessina, F. Local injection of bone marrow progenitor cells for the treatment of anal sphincter injury: In-vitro expanded versus minimally-manipulated cells. Stem Cell Res. Ther. 2016, 7, 1-9. [CrossRef]

38. Kuismanen, K.; Juntunen, M.; Girish, N.N.; Tuominen, H.; Huhtala, H.; Nieminen, K.; Hyttinen, J.; Miettinen, S. Functional Outcome of Human Adipose Stem Cell Injections in Rat Anal Sphincter Acute Injury Model. Stem Cells Transl. Med. 2018, 7, 295-304. [CrossRef]

39. Li, P.; Ma, X.; Jin, W.; Li, X.; Hu, J.; Jiang, X.; Guo, X. Effects of local injection and intravenous injection of allogeneic bone marrow mesenchymal stem cells on the structure and function of damaged anal sphincter in rats. J. Tissue Eng. Regen. Med. 2020, 14, 989-1000. [CrossRef]

40. Salcedo, L.; Penn, M.; Damaser, M.; Balog, B.; Zutshi, M. Functional Outcome After Anal Sphincter Injury and Treatment with Mesenchymal Stem Cells. Stem Cells Transl. Med. 2014, 3, 760-767. [CrossRef] [PubMed]

41. Li, X.; Guo, X.; Jin, W.; Lu, J. Effects of Electroacupuncture Combined with Stem Cell Transplantation on Anal Sphincter Injury-Induced Faecal Incontinence in a Rat Model. Acupunct. Med. 2018, 36, 254-260. [CrossRef] [PubMed]

42. Andrews, V.; Sultan, A.H.; Thakar, R.; Jones, P.W. Occult anal sphincter injuries-myth or reality? BJOG Int. J. Obstet. Gynaecol. 2006, 113, 195-200. [CrossRef] [PubMed]

43. Yamaguchi, I.; Fujita, F.; Yamanouchi, K.; Mishima, T.; Kawahara, D.; Sakai, Y.; Ito, S.; Kanetaka, K.; Takatsuki, M.; Kuroki, T.; et al. A novel animal model of long-term sustainable anal sphincter dysfunction. J. Surg. Res. 2013, 184, 813-818. [CrossRef]

44. Sun, L.; Yeh, J.; Xie, Z.; Kuang, M.; Damaser, M.S.; Zutshi, M. Electrical Stimulation Followed by Mesenchymal Stem Cells Improves Anal Sphincter Anatomy and Function in a Rat Model at a Time Remote from Injury. Dis. Colon Rectum 2016, 59, 434-442. [CrossRef] [PubMed]

45. Montoya, T.I.; Acevedo, J.F.; Smith, B.; Keller, P.W.; Sailors, J.L.; Tang, L.; Word, R.A.; Wai, C.Y. Myogenic stem cell-laden hydrogel scaffold in wound healing of the disrupted external anal sphincter. Int. Urogynecol. J. 2015, 26, 893-904. [CrossRef]

46. Rajasekaran, M.R.; Sinha, S.; Seo, Y.; Salehi, M.; Bhargava, V.; Mittal, R.K. Myoarchitectural and functional alterations in rabbit external anal sphincter muscle following experimental surgical trauma. Am. J. Physiol. Liver Physiol. 2014, 307, G445-G451. [CrossRef] [PubMed]

47. Aghaee-Afshar, M.; Rezazadehkermani, M.; Asadi, A.; Malekpour-Afshar, R.; Shahesmaeili, A.; Nematollahi-Mahani, S.N. Potential of Human Umbilical Cord Matrix and Rabbit Bone Marrow—Derived Mesenchymal Stem Cells in Repair of Surgically Incised Rabbit External Anal Sphincter. Dis. Colon Rectum 2009, 52, 1753-1761. [CrossRef]

48. Kajbafzadeh, A.-M.; Elmi, A.; Talab, S.S.; Esfahani, S.A.; Tourchi, A. Functional External Anal Sphincter Reconstruction for Treatment of Anal Incontinence Using Muscle Progenitor Cell Auto Grafting. Dis. Colon Rectum 2010, 53, 1415-1421. [CrossRef]

49. Kang, S.-B.; Lee, H.S.; Lim, J.-Y.; Oh, S.H.; Kim, S.J.; Hong, S.-M.; Jang, J.-H.; Cho, J.-E.; Lee, S.-M.; Lee, J.H. Injection of porous polycaprolactone beads containing autologous myoblasts in a dog model of fecal incontinence. J. Korean Surg. Soc. 2013, 84, 216-224. [CrossRef]

50. Cherry, D.A.; Rothenberger, D.A. Pelvic Floor Physiology. Surg. Clin. N. Am. 1988, 68, 1217-1230. [CrossRef] 
51. Browning, G.G.P.; Motson, R.W. Anal Sphincter Injury. Management and Results of Parks Sphincter Repair. Ann. Surg. 1984, 199, 351-357. [CrossRef]

52. Walraven, M.; Hinz, B. Therapeutic approaches to control tissue repair and fibrosis: Extracellular matrix as a game changer. Matrix Biol. 2018, 71-72, 205-224. [CrossRef] [PubMed]

53. Ruiz, N.S.; Kaiser, A.M. Fecal incontinence-Challenges and solutions. World J. Gastroenterol. 2017, 23, 11-24. [CrossRef]

54. Frudinger, A.; Pfeifer, J.; Paede, J.; Kolovetsiou-Kreiner, V.; Marksteiner, R.; Halligan, S. Autologous skeletal muscle-derived cell injection for anal incontinence due to obstetric trauma: A five-year follow-up of an initial study of ten patients. Color. Dis. 2015, 17, 794-801. [CrossRef] [PubMed]

55. Romaniszyn, M.; Rozwadowska, N.; Malcher, A.; Kolanowski, T.J.; Walega, P.; Kurpisz, M. Implantation of autologous musclederived stem cells in treatment of fecal incontinence: Results of an experimental pilot study. Tech. Coloproctol. 2015, 19, 685-696. [CrossRef]

56. Frudinger, A.; Marksteiner, R.; Pfeifer, J.; Margreiter, E.; Paede, J.; Thurner, M. Skeletal muscle-derived cell implantation for the treatment of sphincter-related faecal incontinence. Stem Cell Res. Ther. 2018, 9, 1-20. [CrossRef] [PubMed]

57. Boyer, O.; Bridoux, V.; Giverne, C.; Bisson, A.; Koning, E.; Leroi, A.-M.; Chambon, P.; Déhayes, J.; Le Corre, S.; Jacquot, S.; et al. Autologous Myoblasts for the Treatment of Fecal Incontinence: Results of a Phase 2 Randomized Placebo-Controlled Study (MIAS). Ann. Surg. 2018, 267, 443-450. [CrossRef]

58. Bitar, K.N.; Zakhem, E.; Bohl, J.L.; Tamburrini, R.; Dadhich, P.; Scott, C.L.; Knutson, D.T.; Gilliam, J.H. Implantation of Autologous Biosphincters in a Non-Human Primate (NHP) Model of Fecal Incontinence. Gastroenterology 2017, 152, S15. [CrossRef]

59. Dadhich, P.; Bohl, J.L.; Tamburrini, R.; Zakhem, E.; Scott, C.; Kock, N.; Mitchell, E.; Gilliam, J.; Bitar, K.N. BioSphincters to treat Fecal Incontinence in Nonhuman Primates. Sci. Rep. 2019, 9, 1-11. [CrossRef]

60. Araki, J.; Nishizawa, Y.; Fujita, N.; Sato, T.; Iizuka, T.; Kamata, M.; Hatayama, N.; Yakura, T.; Hirai, S.; Tashiro, K.; et al. Anorectal Transplantation: The First Long-Term Success in a Canine Model. Ann Surg. 2021. [CrossRef]

61. Ding, Z.; Liu, X.; Ren, X.; Zhang, Q.; Zhang, T.; Qian, Q.; Liu, W.; Jiang, C. Galectin-1-induced skeletal muscle cell differentiation of mesenchymal stem cells seeded on an acellular dermal matrix improves injured anal sphincter. Dis. Med. 2016, 21, 331-340.

62. Sarveazad, A.; Newstead, G.L.; Mirzaei, R.; Joghataei, M.T.; Bakhtiari, M.; Babahajian, A.; Mahjoubi, B. A new method for treating fecal incontinence by implanting stem cells derived from human adipose tissue: Preliminary findings of a randomized double-blind clinical trial. Stem Cell Res. Ther. 2017, 8, 1-10. [CrossRef] [PubMed]

63. Portilla, F.; Guerrero, J.L.; Maestre, M.V.; Leyva, L.; Mera, S.; García-Olmo, D.; Rodríguez, A.; Mata, R.; Lora, F. Treatment of faecal incontinence with autologous expanded mesenchymal stem cells: Results of a pilot study. Color. Dis. 2020. [CrossRef] [PubMed]

64. Frudinger, A.; Kolle, D.; Schwaiger, W.; Pfeifer, J.; Paede, J.; Halligan, S. Muscle-derived cell injection to treat anal incontinence due to obstetric trauma: Pilot study with 1 year follow-up. Gut 2009, 59, 55-61. [CrossRef]

65. Romaniszyn, M.; Michal, R.; Rozwadowska, N.; Natalia, R.; Nowak, M.; Marcin, N.; Malcher, A.; Agnieszka, M.; Kolanowski, T.; Tomasz, K.; et al. Successful implantation of autologous muscle-derived stem cells in treatment of faecal incontinence due to external sphincter rupture. Int. J. Color. Dis. 2013, 28, 1035-1036. [CrossRef]

66. Frenckner, B.; Euler, C.V. Influence of pudendal block on the function of the anal sphincters. Gut 1975, 16, 482-489. [CrossRef]

67. Burleigh, D.E.; D'Mello, A. Neural and Pharmacologic Factors Affecting Motility of the Internal Anal Sphincter. Gastroenterology 1983, 84, 409-417. [CrossRef]

68. Bitar, K.N.; Raghavan, S. Intestinal tissue engineering: Current concepts and future vision of regenerative medicine in the gut. Neurogastroenterol. Motil. 2011, 24, 7-19. [CrossRef] [PubMed]

69. Szymanski, P.T.; Chacko, T.K.; Rovner, A.S.; Goyal, R.K. Differences in contractile protein content and isoforms in phasic and tonic smooth muscles. Am. J. Physiol. Physiol. 1998, 275, C684-C692. [CrossRef]

70. Somara, S.; Gilmont, R.R.; Dennis, R.G.; Bitar, K.N. Bioengineered Internal Anal Sphincter Derived From Isolated Human Internal Anal Sphincter Smooth Muscle Cells. Gastroenterology 2009, 137, 53-61. [CrossRef] [PubMed]

71. Rattan, S.; Singh, J.; Kumar, S.; Phillips, B. Nature of extracellular signal that triggers RhoA/ROCK activation for the basal internal anal sphincter tone in humans. Am. J. Physiol. Liver Physiol. 2015, 308, G924-G933. [CrossRef]

72. Rattan, S. The internal anal sphincter: Regulation of smooth muscle tone and relaxation. Neurogastroenterol. Motil. 2005, 17, 50-59. [CrossRef]

73. Singh, J.; Boopathi, E.; Addya, S.; Phillips, B.; Rigoutsos, I.; Penn, R.B.; Rattan, S. Aging-associated changes in microRNA expression profile of internal anal sphincter smooth muscle: Role of microRNA-133a. Am. J. Physiol. Liver Physiol. 2016, 311, G964-G973. [CrossRef] [PubMed]

74. Singh, J.; Mohanty, I.; Addya, S.; Phillips, B.; Yong, H.M.; An, S.; Penn, R.B.; Rattan, S. Role of differentially expressed microRNA139-5p in the regulation of phenotypic internal anal sphincter smooth muscle tone. Sci. Rep. 2017, 7, 1-10. [CrossRef]

75. Bitar, K.N. Aging and Gi smooth muscle fecal incontinence: Is bioengineering an option. Exp. Gerontol. 2005, 40, 643-649. [CrossRef]

76. Townsend, M.K.; Matthews, C.A.; Whitehead, W.E.; Grodstein, F. Risk Factors for Fecal Incontinence in Older Women. Am. J. Gastroenterology 2013, 108, 113-119. [CrossRef]

77. Yarandi, S.S.; Srinivasan, S. Diabetic gastrointestinal motility disorders and the role of enteric nervous system: Current status and future directions. Neurogastroenterol. Motil. 2014, 26, 611-624. [CrossRef] 
78. Reszczyńska, M.; Kempiński, R. The Prevalence of Enteropathy Symptoms from the Lower Gastrointestinal Tract and the Evaluation of Anorectal Function in Diabetes Mellitus Patients. J. Clin. Med. 2021, 10, 415. [CrossRef] [PubMed]

79. Papathanasopoulos, A.; Van Oudenhove, L.; Katsanos, K.; Christodoulou, D.; Tack, J.; Tsianos, E.V. Severity of Fecal Urgency and Incontinence in Inflammatory Bowel Disease: Clinical, Manometric and Sonographic Predictors. Inflamm. Bowel Dis. 2013, 19, 2450-2456. [CrossRef]

80. Bassotti, G.; Antonelli, E.; Villanacci, V.; Nascimbeni, R.; Dore, M.P.; Pes, G.M.; Maconi, G. Abnormal gut motility in inflammatory bowel disease: An update. Tech. Coloproctol. 2020, 24, 275-282. [CrossRef]

81. Hosokawa, T.; Konuma, N.; Ikeda, T.; Hashimoto, M.; Kaneda, H.; Ohashi, K.; Matsumoto, T.; Koshinaga, T.; Oohashi, K. Establishment of a new anal sphincter injury model in rats based on cardiotoxin. J. Pediatr. Surg. 2015, 50, 1352-1358. [CrossRef] [PubMed]

82. Kang, S.-B.; Lee, H.N.; Lee, J.Y.; Park, J.-S.; Lee, H.S. Sphincter Contractility After Muscle-Derived Stem Cells Autograft into the Cryoinjured Anal Sphincters of Rats. Dis. Colon Rectum 2008, 51, 1367-1373. [CrossRef]

83. Saihara, R.; Komuro, H.; Urita, Y.; Hagiwara, K.; Kaneko, M. Myoblast transplantation to defecation muscles in a rat model: A possible treatment strategy for fecal incontinence after the repair of imperforate anus. Pediatr. Surg. Int. 2009, 25, 981-986. [CrossRef] [PubMed]

84. Craig, J.B.; Lane, F.L.; Nistor, G.; Motakef, S.; Pham, Q.-A.; Keirstead, H. Allogenic Myoblast Transplantation in the Rat Anal Sphincter. Female Pelvic Med. Reconstr. Surg. 2010, 16, 205-208. [CrossRef] [PubMed]

85. Bisson, A.; Fréret, M.; Drouot, L.; Jean, L.; Le Corre, S.; Gourcerol, G.; Doucet, C.; Michot, F.; Boyer, O.; Lamacz, M. Restoration of Anal Sphincter Function after Myoblast Cell Therapy in Incontinent Rats. Cell Transplant. 2015, 24, 277-286. [CrossRef]

86. Elmi, A.; Kajbafzadeh, A.-M.; Oghabian, M.A.; Talab, S.S.; Tourchi, A.; Khoei, S.; Rafie, B.; Esfahani, S.A. Anal Sphincter Repair With Muscle Progenitor Cell Transplantation: Serial Assessment With Iron Oxide-Enhanced MRI. Am. J. Roentgenol. 2014, 202, 619-625. [CrossRef]

87. Oh, H.-K.; Lee, H.S.; Lee, J.H.; Oh, S.H.; Lim, J.-Y.; Ahn, S.; Kang, S.-B. Coadministration of basic fibroblast growth factor-loaded polycaprolactone beads and autologous myoblasts in a dog model of fecal incontinence. Int. J. Color. Dis. 2015, 30, 549-557. [CrossRef]

88. Oh, H.-K.; Lee, H.S.; Lee, J.H.; Oh, S.H.; Lim, J.-Y.; Ahn, S.; Hwang, J.-Y.; Kang, S.-B. Functional and Histological Evidence for the Targeted Therapy Using Biocompatible Polycaprolactone Beads and Autologous Myoblasts in a Dog Model of Fecal Incontinence. Dis. Colon Rectum 2015, 58, 517-525. [CrossRef]

89. Kajbafzadeh, A.-M.; Kajbafzadeh, M.; Sabetkish, S.; Sabetkish, N.; Tavangar, S.M. Tissue-Engineered External Anal Sphincter Using Autologous Myogenic Satellite Cells and Extracellular Matrix: Functional and Histological Studies. Ann. Biomed. Eng. 2015, 44, 1773-1784. [CrossRef]

90. Son, I.T.; Lee, H.S.; Ihn, M.H.; Lee, K.H.; Kim, D.-W.; Lee, K.-W.; Kim, J.-S.; Kang, S.-B. Isolation of internal and external sphincter progenitor cells from the human anal sphincter with or without radiotherapy. Color. Dis. 2018, 21, 38-47. [CrossRef]

91. Singh, J.; Rattan, S. Bioengineered human IAS reconstructs with functional and molecular properties similar to intact IAS. Am. J. Physiol. Liver Physiol. Gastrointest. 2012, 303, G713-G722. [CrossRef] [PubMed]

92. Gilmont, R.R.; Raghavan, S.; Somara, S.; Bitar, K.N. Bioengineering of Physiologically Functional Intrinsically Innervated Human Internal Anal Sphincter Constructs. Tissue Eng. Part A 2014, 20, 1603-1611. [CrossRef] [PubMed]

93. Raghavan, S.; Miyasaka, E.A.; Gilmont, R.R.; Somara, S.; Teitelbaum, D.H.; Bitar, K.N. Perianal implantation of bioengineered human internal anal sphincter constructs intrinsically innervated with human neural progenitor cells. Surgery 2014, 155, 668-674. [CrossRef] [PubMed]

94. Zakhem, E.; Rego, S.L.; Raghavan, S.; Bitar, K.N. The appendix as a viable source of neural progenitor cells to functionally innervate bioengineered gastrointestinal smooth muscle tissues. Stem Cells Transl. Med. 2015, 4, 548-554. [CrossRef] [PubMed]

95. Rego, S.L.; Raghavan, S.; Zakhem, E.; Bitar, K.N. Enteric neural differentiation in innervated, physiologically functional, smooth muscle constructs is modulated by bone morphogenic protein 2 secreted by sphincteric smooth muscle cells. J. Tissue Eng. Regen. Med. 2015, 11, 1251-1261. [CrossRef]

96. Raghavan, S.; Miyasaka, E.A.; Hashish, M.; Somara, S.; Gilmont, R.R.; Teitelbaum, D.H.; Bitar, K.N. Successful implantation of physiologically functional bioengineered mouse internal anal sphincter. Am. J. Physiol. Liver Physiol. 2010, 299, G430-G439. [CrossRef]

97. Hashish, M.; Raghavan, S.; Somara, S.; Gilmont, R.R.; Miyasaka, E.; Bitar, K.N.; Teitelbaum, D.H. Surgical implantation of a bioengineered internal anal sphincter. J. Pediatr. Surg. 2010, 45, 52-58. [CrossRef] [PubMed]

98. Miyasaka, E.A.; Raghavan, S.; Gilmont, R.R.; Mittal, K.; Somara, S.; Bitar, K.N.; Teitelbaum, D.H. In vivo growth of a bioengineered internal anal sphincter: Comparison of growth factors for optimization of growth and survival. Pediatr. Surg. Int. 2010, 27, 137-143. [CrossRef]

99. Bohl, J.L.; Zakhem, E.; Bitar, K.N. Successful Treatment of Passive Fecal Incontinence in an Animal Model Using Engineered Biosphincters: A 3-Month Follow-Up Study. Stem Cells Transl. Med. 2017, 6, 1795-1802. [CrossRef]

100. Inoue, Y.; Fujita, F.; Yamaguchi, I.; Kinoe, H.; Kawahara, D.; Sakai, Y.; Kuroki, T.; Eguchi, S. Improvement of Anal Function by Adipose-Derived Stem Cell Sheets. Dig. Surg. 2017, 35, 64-69. [CrossRef]

101. Trébol, J.; Georgiev-Hristov, T.; Vega-Clemente, L.; García-Gómez, I.; Carabias-Orgaz, A.; García-Arranz, M.; Olmo, D.G. Rat model of anal sphincter injury and two approaches for stem cell administration. World J. Stem Cells 2018, 10, 1-14. [CrossRef] 
102. Sarveazad, A.; Babahajian, A.; Yari, A.; Rayner, C.K.; Mokhtare, M.; Babaei-Ghazani, A.; Agah, S.; Mahjoubi, B.; Shamseddin, J.; Yousefifard, M. Combination of laser and human adipose-derived stem cells in repair of rabbit anal sphincter injury: A new therapeutic approach. Stem Cell Res. Ther. 2019, 10, 1-15. [CrossRef]

103. Raghavan, S.; Gilmont, R.R.; Miyasaka, E.A.; Somara, S.; Srinivasan, S.; Teitelbaum, D.H.; Bitar, K.N. Successful Implantation of Bioengineered, Intrinsically Innervated, Human Internal Anal Sphincter. Gastroenterology 2011, 141, 310-319. [CrossRef] [PubMed]

104. Tierney, M.T.; Sacco, A. Satellite Cell Heterogeneity in Skeletal Muscle Homeostasis. Trends Cell Biol. 2016, 26, 434-444. [CrossRef]

105. Thurner, M.; Deutsch, M.; Janke, K.; Messner, F.; Kreutzer, C.; Beyl, S.; Couillard-Després, S.; Hering, S.; Troppmair, J.; Marksteiner, R. Generation of myogenic progenitor cell-derived smooth muscle cells for sphincter regeneration. Stem Cell Res. Ther. 2020, 11, 1-17. [CrossRef] [PubMed]

106. Tedesco, F.S.; Moyle, L.; Perdiguero, E. Muscle Interstitial Cells: A Brief Field Guide to Non-satellite Cell Populations in Skeletal Muscle. Methods Mol. Biol. 2017, 1556, 129-147. [CrossRef]

107. Torrente, Y.; Belicchi, M.; Marchesi, C.; D’Antona, G.; Cogiamanian, F.; Pisati, F.; Gavina, M.; Giordano, R.; Tonlorenzi, R.; Fagiolari, G.; et al. Autologous Transplantation of Muscle-Derived CD133+ Stem Cells in Duchenne Muscle Patients. Cell Transplant. 2007, 16, 563-577. [CrossRef] [PubMed]

108. Yang, Z.; Zhang, D.; Wang, L.; Zhang, F.; Li, C.; Zhu, T.; Cao, K.; Ma, W. Nine-year follow-up of local implantation of autologous skeletal myoblasts in a patient with coronary heart disease. Am. J. Case Rep. 2013, 14, 139-142. [CrossRef] [PubMed]

109. Lecoeur, C.; Swieb, S.; Zini, L.; Riviere, C.; Combrisson, H.; Ghérardi, R.; Abbou, C.; Yiou, R. Intraurethral Transfer of Satellite Cells by Myofiber Implants Results in the Formation of Innervated Myotubes Exerting Tonic Contractions. J. Urol. 2007, 178, 332-337. [CrossRef] [PubMed]

110. Abbasi-Malati, Z.; Roushandeh, A.M.; Kuwahara, Y.; Roudkenar, M.H. Mesenchymal Stem Cells on Horizon: A New Arsenal of Therapeutic Agents. Stem Cell Rev. Rep. 2018, 14, 484-499. [CrossRef]

111. Meier, R.P.; Muller, Y.; Morel, P.; Gonelle-Gispert, C.; Buhler, L. Transplantation of mesenchymal stem cells for the treatment of liver diseases, is there enough evidence? Stem Cell Res. 2013, 11, 1348-1364. [CrossRef] [PubMed]

112. Balaphas, A.; Meyer, J.; Sadoul, R.; Morel, P.; Gonelle-Gispert, C.; Buhler, L. Extracellular vesicles: Future diagnostic and therapeutic tools for liver disease and regeneration. Liver Int. 2019, 39, 1801-1817. [CrossRef]

113. Meier, R.P.; Mahou, R.; Morel, P.; Meyer, J.; Montanari, E.; Muller, Y.; Christofilopoulos, P.; Wandrey, C.; Gonelle-Gispert, C.; Bühler, L.H. Microencapsulated human mesenchymal stem cells decrease liver fibrosis in mice. J. Hepatol. $2015,62,634-641$. [CrossRef] [PubMed]

114. Pokrywczynska, M.; Jundzill, A.; Warda, K.; Buchholz, L.; Rasmus, M.; Adamowicz, J.; Bodnar, M.; Marszalek, A.; Helmin-Basa, A.; Michalkiewicz, J.; et al. Does the Mesenchymal Stem Cell Source Influence Smooth Muscle Regeneration in Tissue-Engineered Urinary Bladders? Cell Transplant. 2017, 26, 1780-1791. [CrossRef]

115. Zhang, N.; Qin, X.; Zhang, J.; Zhang, Z.; Li, Y.; Xie, Y.; Kong, D.; Du, R.; Huang, X.; Xu, Y. Bone Marrow Mesenchymal Stem Cells Accelerate the Morphological and Functional Recovery of Neovaginas. Artif. Organs 2018, 42, 1206-1215. [CrossRef]

116. Nakamura, Y.; Miyaki, S.; Ishitobi, H.; Matsuyama, S.; Nakasa, T.; Kamei, N.; Akimoto, T.; Higashi, Y.; Ochi, M. Mesenchymalstem-cell-derived exosomes accelerate skeletal muscle regeneration. FEBS Lett. 2015, 589, 1257-1265. [CrossRef] [PubMed]

117. Linard, C.; Brachet, M.; L'Homme, B.; Strup-Perrot, C.; Busson, E.; Bonneau, M.; Lataillade, J.-J.; Bey, E.; Benderitter, M. Long-term effectiveness of local BM-MSCs for skeletal muscle regeneration: A proof of concept obtained on a pig model of severe radiation burn. Stem Cell Res. Ther. 2018, 9, 1-14. [CrossRef]

118. Hecker, L.; Baar, K.; Dennis, R.G.; Bitar, K.N. Development of a three-dimensional physiological model of the internal anal sphincter bioengineered in vitro from isolated smooth muscle cells. Am. J. Physiol. Liver Physiol. Gastrointest. 2005, 289, G188-G196. [CrossRef] [PubMed]

119. Dominici, M.; Le Blanc, K.; Mueller, I.; Slaper-Cortenbach, I.; Marini, F.; Krause, D.; Deans, R.; Keating, A.; Prockop, D.; Horwitz, E. Minimal criteria for defining multipotent mesenchymal stromal cells. The International Society for Cellular Therapy position statement. Cytotherapy 2006, 8, 315-317. [CrossRef]

120. Gräs, S.; Tolstrup, C.K.; Lose, G. Regenerative medicine provides alternative strategies for the treatment of anal incontinence. Int. Urogynecol. J. 2016, 28, 341-350. [CrossRef]

121. Baldari, S.; Di Rocco, G.; Piccoli, M.; Pozzobon, M.; Muraca, M.; Toietta, G. Challenges and Strategies for Improving the Regenerative Effects of Mesenchymal Stromal Cell-Based Therapies. Int. J. Mol. Sci. 2017, 18, 2087. [CrossRef] [PubMed]

122. Bols, E.M.J.; Hendriks, H.J.M.; Berghmans, L.C.M.; Baeten, C.G.M.I.; De Bie, R.A. Responsiveness and interpretability of incontinence severity scores and FIQL in patients with fecal incontinence: A secondary analysis from a randomized controlled trial. Int. Urogynecol. J. 2012, 24, 469-478. [CrossRef] [PubMed]

123. der Zalm, P.J.V.-V.; Voorham, J.C.; Bos, T.W.V.D.; Ouwerkerk, T.J.; Putter, H.; Wasser, M.N.; Webb, A.; DeRuiter, M.C.; Pelger, R. Reliability and differentiation of pelvic floor muscle electromyography measurements in healthy volunteers using a new device: The multiple array probe leiden (MAPLe). Neurourol. Urodynamics 2012, 32, 341-348. [CrossRef]

124. Johnson, E.; Carlsen, E.; Steen, T.B.; Hjorthaug, J.O.B.; Eriksen, M.T.; Johannessen, H.-O. Short- and long-term results of secondary anterior sphincteroplasty in 33 patients with obstetric injury. Acta Obstet. Gynecol. Scand. 2010, 89, 1466-1472. [CrossRef] [PubMed] 
125. Lamblin, G.; Bouvier, P.; Damon, H.; Chabert, P.; Moret, S.; Chene, G.; Mellier, G. Long-term outcome after overlapping anterior anal sphincter repair for fecal incontinence. Int. J. Color. Dis. 2014, 29, 1377-1383. [CrossRef]

126. Garcia, S.; Bernad, A.; Martín, M.C.; Cigudosa, J.C.; Garcia-Castro, J.; de la Fuente, R. Pitfalls in spontaneous in vitro transformation of human mesenchymal stem cells. Exp. Cell Res. 2010, 316, 1648-1650. [CrossRef]

127. Torsvik, A.; Røsland, G.V.; Svendsen, A.; Molven, A.; Immervoll, H.; Mc Cormack, E.; Lonning, P.E.; Primon, M.; Sobala, E.; Tonn, J.-C.; et al. Spontaneous Malignant Transformation of Human Mesenchymal Stem Cells Reflects Cross-Contamination: Putting the Research Field on Track-Letter: Table 1. Cancer Res. 2010, 70, 6393-6396. [CrossRef]

128. Trébol, J.; Carabias-Orgaz, A.; García-Arranz, M.; Olmo, D.G. Stem cell therapy for faecal incontinence: Current state and future perspectives. World J. Stem Cells 2018, 10, 82-105. [CrossRef]

129. Lipsitz, Y.Y.; Milligan, W.D.; Fitzpatrick, I.; Stalmeijer, E.; Farid, S.; Tan, K.Y.; Smith, D.; Perry, R.; Carmen, J.; Chen, A.; et al. A roadmap for cost-of-goods planning to guide economic production of cell therapy products. Cytotherapy 2017, 19, 1383-1391. [CrossRef] [PubMed]

130. Balaphas, A.; Schiltz, B.; Liot, E.; Robert-Yap, J.; Ris, F. What is the role of stem cell therapy in the treatment of anal incontinence? Color. Dis. 2020, 23, 551-552. [CrossRef] [PubMed]

131. de la Portilla, F. Reply to Balaphas et al. Colorectal Dis. 2021, 23, 1002-1003. [CrossRef] [PubMed] 